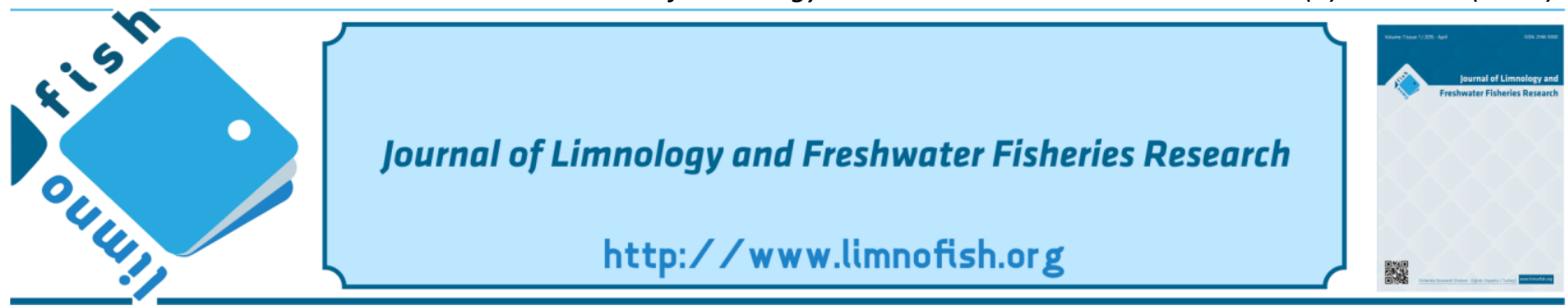

\title{
Seasonal Change of Physicochemical Properties of Kayalıköy Reservoir (Kıklareli/Turkey) and Determination of Water Quality
}

\author{
Hüseyin GÜHER * iD Burak ÖTERLER \\ Trakya University Faculty of Science, Department of Biology, 22030, Edirne, Turkey
}

\section{A B STR ACT}

This study was carried out in the Kayalıköy reservoir (Kırklareli, Turkey), that is used for agricultural irrigation and aquaculture and to provide drinking and domestic water supply of Edirne province. The study was performed at 3 stations determined in the reservoir during a year from May 2018 to April 2019. The water samples were taken with Ruttner water sample bottles from 15 to $20 \mathrm{~cm}$ below the water surface. Water temperature, Secchi disk depth, conductivity, $\mathrm{pH}$, and dissolved oxygen were measured on-site simultaneously with the sampling time. Other physicochemical parameters were analyzed in the laboratory. A total of 43 physicochemical parameters were measured in the Kayalıköy reservoir. Analysis results obtained are compared with Regulation on Modification of Surface Water Quality Management (RSWQM) and Regulation on the Quality and Treatment of Water Provided for Drinking Water (RDWQ). According to the average values of the analysis results the water quality in Kayalıköy reservoir determined generally to be Class I and A1 water. In conclusion, Kayalıköy reservoir has water suitable for drinking, agricultural irrigation, and aquaculture and was classified as having oligomesotrophic character.

Keywords: Reservoir, water quality, physicochemical

\section{ARTICLE INFO}

\section{RESEARCH ARTICLE}

$\begin{array}{lll}\text { Received } & : 18.12 .2019 \\ \text { Revised } & : 11.03 .2020 \\ \text { Accepted } & : 25.03 .2020 \\ \text { Published } & : 27.08 .2020\end{array}$

DOI:10.17216/LimnoFish.660975

* CORRESPONDING AUTHOR

huseying@trakya.edu.tr

Phone : +905324030306

Kayalıköy Barajı’nın (Kırklareli/Türkiye) Fizikokimyasal Özelliklerinin Mevsimsel Değişimi ve Su Kalitesinin Belirlenmesi

Öz: Bu çalışma, Edirne ilinin içme ve kullanma suyu ile birlikte tarımsal sulama ve su ürünleri yetiştiriciliğginde kullanılan Kayalıköy baraj gölünde yapılmıştır. Su kalitesini belirlemeye yönelik olan bu araştırma, Mayıs 2018-Nisan 2019 tarihleri arasında bir yıl boyunca baraj gölünde seçilen 3 istasyonda gerçekleştirilmiştir. Bazı fizikokimyasal parametreler (su sıcaklığı, 1şık geçirgenliği, iletkenlik, pH ve çözünmüş oksijen) araştırma sırasında ölçülürken diğer analizler için su örnekleri, su yüzeyinin $15-20 \mathrm{~cm}$ altında Ruttner şişesi ile alınmış ve analizleri laboratuvarda yapılmıştır. Toplam 43 fizikokimyasal parametreler ölçülmüștür. Elde edilen analiz sonuçları, Yüzeysel Su Kalitesi Yönetiminde Değişiklik Yapılmasına Dair Yönetmelik (RSWQM) ve İçme Suyu İçin Sağlanan Suyun Kalitesi ve Arıtımı Yönetmeliği (RDWQ) ile karşılaştırılmıştır. Analiz sonuçlarının ortalamalarına göre Kayalıköy rezervuarındaki su kalitesi genel olarak I sınıf ve A1 su olarak belirlenmiştir. Sonuç olarak, Kayalıköy rezervuarı içme, tarımsal sulama ve su ürünleri yetiştiriciliği için uygun suya sahip olduğu ve baraj gölünün oligomesotrofik karakterde olduğu tespit edilmiştir.

Anahtar kelimeler: Baraj gölü, su kalitesi, fizikokimyasal

\section{How to Cite}

Güher H, Öterler B. 2020. Seasonal Change of Physicochemical Properties of Kayalıköy Reservoir (K1klareli/Turkey) and Determination of Water Quality. LimnoFish. 6(2): 127-143. doi: 10.17216/LimnoFish.660975

\section{Introduction}

Reservoirs are water bodies formed or modified by human activity for specific purposes to provide a reliable and controllable resource. Historically, reservoirs were built to serve a single purpose, i.e. irrigation. The present-day dam reservoirs, which are constructed for various reasons including flood control, water storage for water supply and irrigation, hydropower, fisheries, and recreation, show the characteristics of both rivers and lakes.

The physicochemical and biological properties of water in reservoirs often vary depending on the characteristics of the streams that feed the reservoir and the hydraulic residence time in the reservoir (Gikas et al. 2009). 
Reservoir differs from natural lakes due to high external nutrient input, large drainage basin, water level changes, and human activity (Thornton et al. 1990). Freshwater pollution is a matter of serious global concern today and unfortunately, water resources subject to continuous pollution increasing gradually day by day (Strobl and Robillard 2008). Many researches showed that water sources are mostly contaminated as a result of human activities, particularly with domestic and industrial wastes, in addition to natural factors like rainwater, material transport with surface waters, atmospheric transport, and plant pollens (Samian et al. 2015; Loukas 2010). Pollutants discharged into water disturb the balance of the ecosystem and lead to significant problems in terms of public health by impairing the quality of domestic and drinking water. Since rivers and lakes are the major water resources for domestic use and human consumption, the accumulation of contaminants here constitute a global health problem (Das Kangabam and Govindaraju 2017).

It is required to assess a large number of physicochemical water quality data for effective contamination control. Water quality assessment is also useful and necessary for effective management of water resources (Dixon and Chiswell 1996; Köse et al. 2014). For this purpose, many studies have been conducted to determine the water quality of freshwater ecosystems such as streams, lakes, dams
(Kükrer and Mutlu 2019; Mutlu et al. 2016; Minareci and Çakır 2018; Uncumusaoğlu and Mutlu 2017; Bulut and Kubilay 2018; Tepe and Kutlu 2019).

In this study, it was aimed to determine the water quality of Kayalıköy reservoir located in Kırklareli Province, Turkey by examining the physicochemical parameters of reservoir water which is used as domestic and drinking water of Edirne province.

\section{Materials and Methods}

Kayalıköy Reservoir was built 1981-1986 for irrigation and flood control on Teke Stream and it takes the name from Kayal1 village to the west of the dam. The reservoir is west of Kirklareli and $12 \mathrm{~km}$ from Kurklareli city center. (400 48'51''N, 260 $47^{\prime} 43^{\prime}$ 'E). Because it is surrounded by rock formations, both the lake and the littoral region lack water plants. Kayalıköy Reservoir has volume is $144.2 \mathrm{hm}^{3}$ and a surface area of $10.20 \mathrm{~km}^{2}$. Although the reservoir is fed mainly by the Teke stream, it is also replenished by other small streams in the region and rainfall. Although the reservoir was built for irrigation and flood control, it is also provides drinking and domestic water of Edirne.

The samples were collected monthly during the year May 2018 to April 2019 in three different stations in the reservoir that were considered to represent the entire lake (Figure 1 and Table 1).

Table 1. Sampling stations and coordinates in the Kayalıöy reservoir

\begin{tabular}{|c|c|c|}
\hline Sampling stations & Explanations & Geographic coordinates \\
\hline $1^{\text {st }}$ station & $\begin{array}{l}\text { This station is located on the western branch of the lake and } \\
\text { where Teke stream feeding the lake is located. }\end{array}$ & 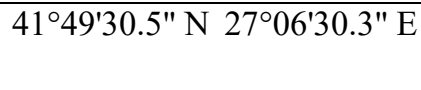 \\
\hline $2^{\text {nd }}$ station & $\begin{array}{l}\text { This station is the middle part of the reservoir. Water in the } \\
\text { reservoir is discharged in this area for irrigation and drinking } \\
\text { water supply. }\end{array}$ & $41^{\circ} 47^{\prime} 28.3^{\prime \prime} \mathrm{N} 27^{\circ} 08^{\prime} 07.3^{\prime \prime} \mathrm{E}$ \\
\hline $3^{\text {rd }}$ station & $\begin{array}{l}\text { This sampling station is located on the eastern branch of the } \\
\text { lake }\end{array}$ & $41^{\circ} 48^{\prime} 06.0^{\prime \prime} \mathrm{N} 27^{\circ} 09^{\prime} 13.1^{\prime \prime} \mathrm{E}$ \\
\hline
\end{tabular}

The water samples were taken with Ruttner water sample bottles from 15 to $20 \mathrm{~cm}$ below the water surface. Some physicochemical parameters (water temperature, Secchi disk depth, conductivity, $\mathrm{pH}$, and dissolved oxygen) were measured on-site simultaneously with the sampling time in with Orion Star S/N 610541. The samples were transported to the laboratory in iceboxes and stored in the refrigerator at $4{ }^{\circ} \mathrm{C}$ until analysis. The values of Chlorophyll-a (Chl-a), Total dissolved solids matter (TDS), Nitrite nitrogen $\left(\mathrm{NO}_{2}-\mathrm{N}\right)$, Nitrate nitrogen $\left(\mathrm{NO}_{3}-\mathrm{N}\right)$, Phosphate $\left(\mathrm{PO}_{4}\right)$, Chlorine $\left(\mathrm{Cl}_{2}\right)$, Sulphate $\left(\mathrm{SO}_{4}{ }^{2-}\right)$, Fluoride $\left(\mathrm{F}^{-}\right)$, Chloride $(\mathrm{Cl}-)$, Bromide
(Br-), Bromate $\left(\mathrm{BrO}_{3}\right)$, Sodium (Na), Magnesium $(\mathrm{Mg})$, Potassium (K), Calcium (Ca), Lithium (Li), Beryllium (Be), Boron (B), Aluminium (Al), Iron, (F) Stronsiyum (Sr), Vanadium (V), Chromium (Cr), Manganese (Mn), Cobalt (Co), Nickel (Ni), Copper $(\mathrm{Cu})$, Zinc (Zn), Arsenic (As), Selenium (Se), Molybdenum (Mo), Cadmium (Cd), Antimony ( $\mathrm{Sb}$ ), Barium $(\mathrm{Ba})$, Thallium $(\mathrm{Tl})$ and Lead $(\mathrm{Pb})$ were measured in laboratories of Trakya University Technology Research Development Application and Research Center (TUTAGEM). A total of 43 parameters were analyzed in reservoir water. The analysis of the ions was performed by 
Metrohm Ion Chromatography System using EPA 300.1 method. Metal analyzes were read on the Agilent Technologies 7700 ICP-MS System using EPA 200.7 and EPA 200.8 methods (EPA 2001).

The results were compared by National Standart for Turkish inland water Regulation on Modification of Surface Water Quality Management (RSWQM
2015) and Regulation on the Quality and Treatment of Water Provided for Drinking Water (RDWQ 2019) and the water quality of Kayalıköy reservoir was classified accordingly. Besides, besides, Spearmans Correlation was used to determine the related environmental parameters with each other (Krebs 1999). Statistical analyses were performed using SPSS 17.0.

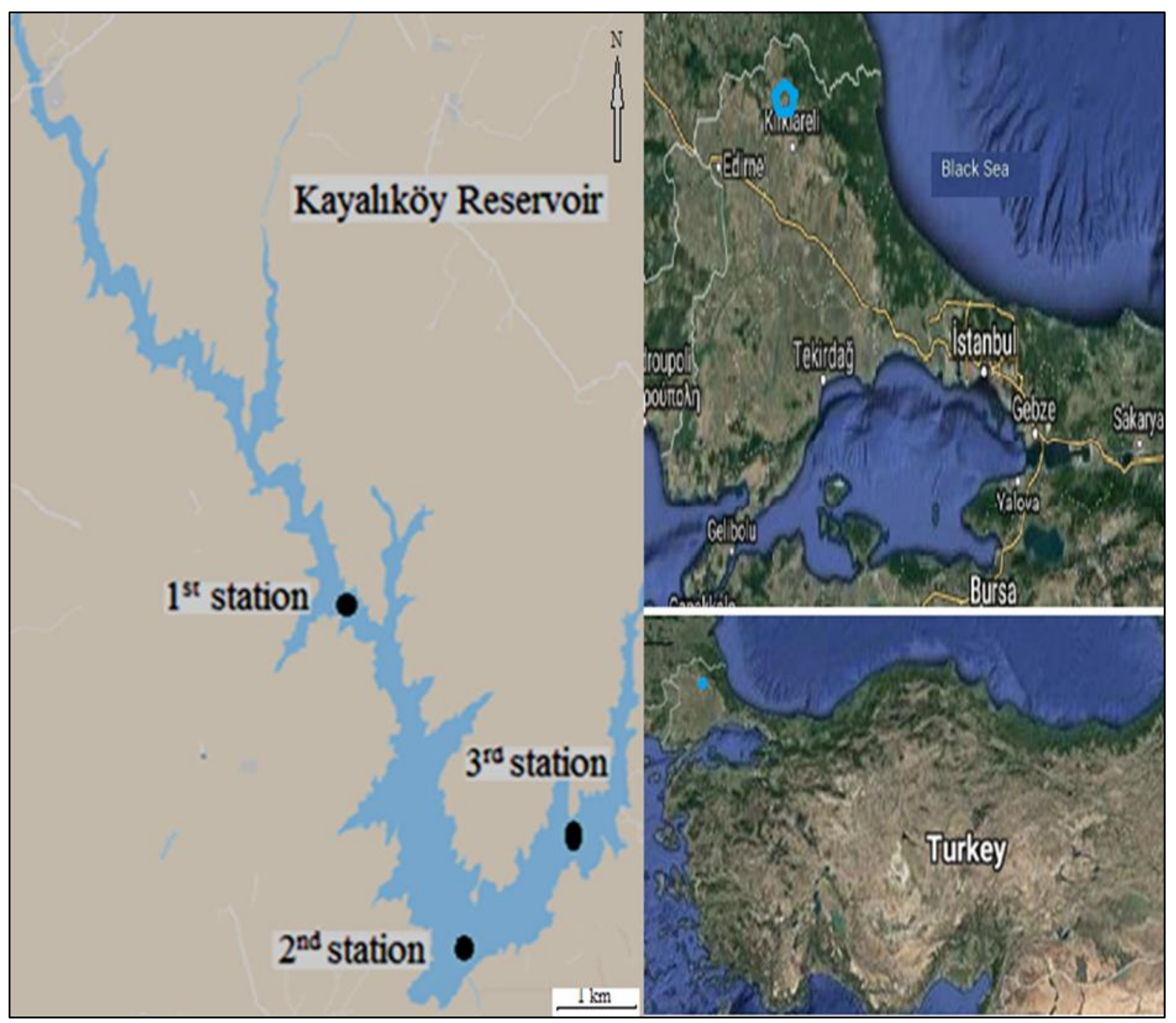

Figure 1. Location of Kayalıköy reservoir and the sampling stations

\section{Results}

According to the analysis results, regardless of difference of seasons and stations, the annual mean values of water quality parameters were found as Water temperature (WT) $\left(15.530 \pm 7.74{ }^{\circ} \mathrm{C}\right)$, Secchi disk depth (SD) $(94.242 \pm 39.34 \mathrm{~cm})$, Chlorophyll-a (Chl-a) $(10.713 \pm 7.00 \mu \mathrm{g} / \mathrm{L})$, Total dissolved solids matter (TDS) $(126.395 \pm 21.09 \mathrm{mg} / \mathrm{L})$, Nitrite nitrogen $\left(\mathrm{NO}_{2}-\mathrm{N}\right)(0.054 \pm 0.05 \mathrm{mg} / \mathrm{L})$, Nitrate nitrogen $\left(\mathrm{NO}_{3}-\right.$ N) $(2.458 \pm 1.67 \mathrm{mg} / \mathrm{L})$, Phosphate $\left(\mathrm{PO}_{4}\right)(0.126 \pm 0.24$ $\mathrm{mg} / \mathrm{L})$, Chlorine $\left(\mathrm{Cl}_{2}\right)(15.675 \pm 6.38 \mathrm{mg} / \mathrm{L})$, Sulphate $\left(\mathrm{SO}_{4}{ }^{2-}\right) \quad(15.999 \pm 0.78 \mathrm{mg} / \mathrm{L})$, Fluoride $\left(\mathrm{F}^{-}\right)$ $(0.155 \pm 0.01 \mathrm{mg} / \mathrm{L})$, Chloride $\left(\mathrm{Cl}^{-}\right) \quad(0.122 \pm 0.11$ $\mathrm{mg} / \mathrm{L})$, Bromide $\left(\mathrm{Br}^{-}\right)(0.044 \pm 0.02 \mathrm{mg} / \mathrm{L})$, Bromate
$\left(\mathrm{BrO}_{3}\right)(0.243 \pm 0.20 \mathrm{mg} / \mathrm{L})$, Sodium (Na) $(7.304 \pm 4.08$ $\mathrm{mg} / \mathrm{L})$, Magnesium (Mg) $(5.613 \pm 2.71 \mathrm{mg} / \mathrm{L})$, Potassium (K) (8.691 \pm 8.58$)$, Calcium (Ca) $(12.060 \pm 6.34 \mathrm{mg} / \mathrm{L})$, Lithium (Li) $\quad(3.261 \pm 1.89$ $\mu \mathrm{g} / \mathrm{L})$, Beryllium (Be) $(0.230 \pm 0.33 \mu \mathrm{g} / \mathrm{L})$, Boron (B) $(40.342 \pm 23.61 \quad \mu \mathrm{g} / \mathrm{L}), \quad$ Aluminium $\quad(\mathrm{Al})$ $(139.261 \pm 163.34 \mu \mathrm{g} / \mathrm{L})$, Iron (F) $(0.142 \pm 0.09 \mu \mathrm{g} / \mathrm{L})$, Stronsiyum (Sr) $(89.538 \pm 42.51 \mu \mathrm{g} / \mathrm{L})$, Vanadium $(\mathrm{V})$ $(3.362 \pm 3.55 \mu \mathrm{g} / \mathrm{L})$, Chromium (Cr) $\quad(2.786 \pm 3.00$ $\mu \mathrm{g} / \mathrm{L})$, Manganese $(\mathrm{Mn})(5.078 \pm 3.93 \mu \mathrm{g} / \mathrm{L})$, Cobalt (Co) $(0.186 \pm 0.09 \mu \mathrm{g} / \mathrm{L})$, Nickel (Ni) $(1.509 \pm 0.62$ $\mu \mathrm{g} / \mathrm{L})$, Copper $(\mathrm{Cu})(1.769 \pm 1.74 \mu \mathrm{g} / \mathrm{L})$, Zinc $(\mathrm{Zn})$ $(3.585 \pm 2.52 \mu \mathrm{g} / \mathrm{L})$, Arsenic (As) $(0.726 \pm 0.42 \mu \mathrm{g} / \mathrm{L})$, Selenium (Se) $(7.046 \pm 5.56 \mu \mathrm{g} / \mathrm{L})$, Molybdenum 
(Mo) $(4.071 \pm 10.85 \mu \mathrm{g} / \mathrm{L})$, Cadmium $(\mathrm{Cd})$ $(0.097 \pm 0.07 \mu \mathrm{g} / \mathrm{L})$, Antimony (Sb) (22.191 \pm 59.28$)$, Barium (Ba) $(23.482 \pm 11.91 \mu \mathrm{g} / \mathrm{L})$, Thallium (T1) $(0.119 \pm 0.08 \mu \mathrm{g} / \mathrm{L})$ and Lead $(\mathrm{Pb})(0.873 \pm 0.73 \mu \mathrm{g} / \mathrm{L})$ (Table 2).

The minimum and maximum values of the physicochemical parameters measured in the Kayalıköy reservoir are given in Table 2 in a monthly and seasonally manner. Besides, according to months the change of physicochemical parameters is given in Figure 2.

According to the Spearmans Correlation, While water temperature (WT) showed positive significant relationship with $\mathrm{SD}(\mathrm{r}=752), \mathrm{Chl}-a(\mathrm{r}=882), \mathrm{SO}_{4}$ $(\mathrm{r}=882) \quad(\mathrm{p}<0,01) ; \mathrm{Fe}(\mathrm{r}=724), \mathrm{Cr} \quad(\mathrm{r}=627)$ and $\mathrm{Tl}$ $(\mathrm{r}=645) \quad(\mathrm{p}<0,05)$, it showed negative relationship with DO ( $\mathrm{r}=809), \mathrm{Al}(\mathrm{r}=845)(\mathrm{p}<0,01)$ and $\mathrm{Fe}(\mathrm{r}=724)$ $(\mathrm{p}<0,05)$ (Table 3). While Secchi disk depth (SD) showed positive significant relationship with $\mathrm{NO}_{3}$ $(\mathrm{r}=806), \quad \mathrm{SO}_{4} \quad(\mathrm{r}=916), \quad \mathrm{Cr} \quad(\mathrm{r}=765) \quad(\mathrm{p}<0.01)$; Chl- $a(\mathrm{r}=620), \mathrm{Na}(\mathrm{r}=706), \mathrm{Mg}(\mathrm{r}=656), \mathrm{Cu}(\mathrm{r}=615)$ and $\mathrm{Se} \quad(\mathrm{r}=638) \quad(\mathrm{p}<0,05)$, it showed negative relationship with DO $(\mathrm{r}=852)(\mathrm{p}<0.01)$ (Table 3$)$. While Chlorophyll-a (Chl-a) showed positive significant relationship with WT $(\mathrm{r}=882)$, $\mathrm{SO}_{4}(\mathrm{r}=727), \mathrm{Tl}(\mathrm{r}=764)(\mathrm{p}<0.01)$ and SD $(\mathrm{r}=620)$ $(\mathrm{P}<0.05)$, it showed negative relationship with $\mathrm{Al}$ $(\mathrm{r}=791) \quad(\mathrm{p}<0.01), \quad \mathrm{DO} \quad(\mathrm{r}=682), \quad \mathrm{NO}_{3} \quad(\mathrm{r}=655)$, $\mathrm{PO}_{4}(\mathrm{r}=639)$ and $\mathrm{Fe}(\mathrm{r}=620) \quad(\mathrm{P}<0.05) \quad($ Table 3$)$. While Dissolved oxygen (DO) showed positive significant relationship with $\mathrm{Al}(\mathrm{r}=791)(\mathrm{p}<0.01)$, it showed negative relationship with WT $(\mathrm{r}=809)$, SD $(\mathrm{r}=852), \quad \mathrm{SO}_{4} \quad(\mathrm{r}=936), \quad \mathrm{Cr} \quad(\mathrm{r}=754) \quad(\mathrm{p}<0.01)$, Chl-a (r=682), $\quad \mathrm{NO}_{2} \quad(\mathrm{r}=664), \quad \mathrm{Na} \quad(\mathrm{r}=618)$, and $\mathrm{Tl} \quad(\mathrm{r}=609) \quad(\mathrm{p}<0.05) \quad($ Table 3$)$. According to the Spearmans Correlation, the relationship of the other parameters with each other is given in Table 3.

Table 2. According to months and seasons maximum and minimum values of physicochemical parameters measured in Kayalıköy reservoir

\begin{tabular}{|c|c|c|c|c|c|c|}
\hline & \multirow[b]{2}{*}{ Abbreviation } & \multicolumn{2}{|c|}{$\begin{array}{l}\text { According to } \\
\text { months }\end{array}$} & \multicolumn{2}{|c|}{$\begin{array}{l}\text { According to the } \\
\text { seasons }\end{array}$} & \multirow{2}{*}{$\begin{array}{l}\text { Average of } \\
\text { reservoir }\end{array}$} \\
\hline & & Min & Max & Min & Max & \\
\hline Air temperature & $\mathrm{AT}\left({ }^{\circ} \mathrm{C}\right)$ & 3.333 & 30.000 & 5.111 & 27.333 & $17.136 \pm 9.06$ \\
\hline Water temperature & $\mathrm{WT}\left({ }^{\circ} \mathrm{C}\right)$ & 4.167 & 26.500 & 5.722 & 25.056 & $15.530 \pm 7.74$ \\
\hline Secchi disk depth & $\mathrm{SD}(\mathrm{cm})$ & 36.667 & 186.667 & 50.000 & 130.000 & $94.242 \pm 39.34$ \\
\hline Chlorophyll-a & Chl- $a(\mu \mathrm{g} / \mathrm{L})$ & 4.333 & 23.833 & 4.833 & 16.257 & $10.713 \pm 7.00$ \\
\hline Dissolved oxygen & DO $(\mathrm{mg} / \mathrm{L})$ & 8.487 & 13.760 & 8.653 & 13.760 & $10.277 \pm 1.66$ \\
\hline $\mathrm{pH}$ & $\mathrm{pH}$ & 6.360 & 9.477 & 8.173 & 9.108 & $8.435 \pm 0.79$ \\
\hline Salinity & Salinity (psu) & 0.138 & 0.201 & 0.152 & 0.182 & $0.171 \pm 0.02$ \\
\hline Electrical conductivity & $\mathrm{EC}(\mu \mathrm{S} / \mathrm{cm})$ & 177.233 & 319.767 & 201.967 & 278.167 & $249.936 \pm 41.91$ \\
\hline Total dissolved solids matter & TDS (mg/L) & 88.010 & 157.200 & 100.967 & 136.789 & $126.395 \pm 21.09$ \\
\hline Nitrite nitrogen & $\mathrm{NO}_{2}-\mathrm{N} \quad(\mathrm{mg} / \mathrm{L})$ & 0.002 & 0.131 & 0.008 & 0.120 & $0.054 \pm 0.05$ \\
\hline Nitrate nitrogen & $\mathrm{NO}_{3}-\mathrm{N} \quad(\mathrm{mg} / \mathrm{L})$ & 0.062 & 4.967 & 0.726 & 3.937 & $2.458 \pm 1.67$ \\
\hline Phosphate & $\mathrm{PO}_{4} \quad(\mathrm{mg} / \mathrm{L})$ & 0.000 & 0.839 & 0.004 & 0.422 & $0.126 \pm 0.24$ \\
\hline Chlorine & $\mathrm{Cl}_{2} \quad(\mathrm{mg} / \mathrm{L})$ & 8.859 & 25.767 & 9.635 & 21.583 & $15.675 \pm 6.38$ \\
\hline Sulfate & $\mathrm{SO}_{4}{ }^{2-}(\mathrm{mg} / \mathrm{L})$ & 14.665 & 17.076 & 14.830 & 16.594 & $15.999 \pm 0.78$ \\
\hline Fluoride & $\mathrm{F}^{-}(\mathrm{mg} / \mathrm{L})$ & 0.140 & 0.166 & 0.146 & 0.163 & $0.155 \pm 0.01$ \\
\hline Chloride & $\mathrm{Cl}^{-}(\mathrm{mg} / \mathrm{L})$ & 0.040 & 0.338 & 0.049 & 0.227 & $0.122 \pm 0.11$ \\
\hline Bromide & $\mathrm{Br}^{-} \quad(\mathrm{mg} / \mathrm{L})$ & 0.000 & 0.059 & 0.027 & 0.056 & $0.044 \pm 0.02$ \\
\hline Bromate & $\mathrm{BrO}_{3}(\mathrm{mg} / \mathrm{L})$ & 0.000 & 0.560 & 0.146 & 0.351 & $0.243 \pm 0.20$ \\
\hline Sodium & $\mathrm{Na}(\mathrm{mg} / \mathrm{L})$ & 1.894 & 12.695 & 2.215 & 11.010 & $7.304 \pm 4.08$ \\
\hline Magnesium & $\mathrm{Mg}(\mathrm{mg} / \mathrm{L})$ & 1.349 & 8.899 & 2.969 & 7.930 & $5.613 \pm 2.71$ \\
\hline Potassium & $\mathrm{K}(\mathrm{mg} / \mathrm{L})$ & 0.718 & 25.019 & 1.622 & 18.135 & $8.691 \pm 8.58$ \\
\hline Calcium & $\mathrm{Ca}(\mathrm{mg} / \mathrm{L})$ & 2.646 & 23.479 & 6.736 & 17.633 & $12.060 \pm 6.34$ \\
\hline Lithium & $\mathrm{Li}(\mu \mathrm{g} / \mathrm{L})$ & 0.773 & 5.530 & 0.773 & 4.774 & $3.261 \pm 1.89$ \\
\hline Beryllium & $\mathrm{Be}(\mu \mathrm{g} / \mathrm{L})$ & 0.035 & 1.120 & 0.045 & 1.120 & $0.230 \pm 0.33$ \\
\hline Boron & $\mathrm{B}(\mu \mathrm{g} / \mathrm{L})$ & 15.236 & 101.169 & 15.971 & 68.927 & $40.342 \pm 23.61$ \\
\hline
\end{tabular}


Tablo 2. Devami.

\begin{tabular}{|c|c|c|c|c|c|c|}
\hline & \multirow[b]{2}{*}{ Abbreviation } & \multicolumn{2}{|c|}{$\begin{array}{c}\begin{array}{c}\text { According to } \\
\text { months }\end{array} \\
\end{array}$} & \multicolumn{2}{|c|}{$\begin{array}{c}\text { According to the } \\
\text { seasons }\end{array}$} & \multirow{2}{*}{$\begin{array}{l}\text { Average of } \\
\text { reservoir }\end{array}$} \\
\hline & & Min & Max & Min & Max & \\
\hline Aluminum & $\mathrm{Al}(\mu \mathrm{g} / \mathrm{L})$ & 6.475 & 612.883 & 41.961 & 323.348 & $139.261 \pm 163.34$ \\
\hline Iron & $\mathrm{Fe}(\mathrm{mg} / \mathrm{L})$ & 0.072 & 0.401 & 0.088 & 0.222 & $0.142 \pm 0.09$ \\
\hline Stronsiyum & $\mathrm{Sr}(\mu \mathrm{g} / \mathrm{L})$ & 22.133 & 144.727 & 53.945 & 129.161 & $89.538 \pm 42.51$ \\
\hline Vanadium & $\mathrm{V}(\mu \mathrm{g} / \mathrm{L})$ & 0.391 & 11.978 & 0.727 & 7.885 & $3.362 \pm 3.55$ \\
\hline Chromium & $\mathrm{Cr}(\mu \mathrm{g} / \mathrm{L})$ & 0.408 & 11.465 & 1.142 & 6.500 & $2.786 \pm 3.00$ \\
\hline Manganese & $\operatorname{Mn}(\mu \mathrm{g} / \mathrm{L})$ & 1.659 & 14.601 & 3.303 & 8.702 & $5.078 \pm 3.93$ \\
\hline Cobalt & $\mathrm{Co}(\mu \mathrm{g} / \mathrm{L})$ & 0.039 & 0.333 & 0.073 & 0.269 & $0.186 \pm 0.09$ \\
\hline Nickel & $\mathrm{Ni}(\mu \mathrm{g} / \mathrm{L})$ & 0.418 & 2.485 & 0.971 & 1.866 & $1.509 \pm 0.62$ \\
\hline Copper & $\mathrm{Cu}(\mu \mathrm{g} / \mathrm{L})$ & 0.348 & 6.796 & 0.866 & 3.572 & $1.769 \pm 1.74$ \\
\hline Zinc & $\mathrm{Zn}(\mu \mathrm{g} / \mathrm{L})$ & 0.818 & 9.145 & 1.987 & 6.597 & $3.585 \pm 2.52$ \\
\hline Arsenic & As $(\mu \mathrm{g} / \mathrm{L})$ & 0.077 & 1.386 & 0.394 & 1.183 & $0.726 \pm 0.42$ \\
\hline Selenium & $\operatorname{Se}(\mu \mathrm{g} / \mathrm{L})$ & 0.270 & 19.148 & 2.134 & 10.310 & $7.046 \pm 5.56$ \\
\hline Molybdenum & Mo $(\mu \mathrm{g} / \mathrm{L})$ & 0.602 & 33.543 & 0.909 & 20.698 & $14.071 \pm 10.85$ \\
\hline Cadmium & $\mathrm{Cd}(\mu \mathrm{g} / \mathrm{L})$ & 0.008 & 0.260 & 0.024 & 0.167 & $0.097 \pm 0.07$ \\
\hline Antimony & $\mathrm{Sb}(\mu \mathrm{g} / \mathrm{L})$ & 0.053 & 199.900 & 0.279 & 104.403 & $22.191 \pm 59.28$ \\
\hline Barium & $\mathrm{Ba}(\mu \mathrm{g} / \mathrm{L})$ & 5.486 & 42.963 & 16.058 & 34.938 & $23.482 \pm 11.91$ \\
\hline Thallium & $\mathrm{Tl}(\mu \mathrm{g} / \mathrm{L})$ & 0.012 & 0.260 & 0.033 & 0.191 & $0.119 \pm 0.08$ \\
\hline Lead & $\mathrm{Pb}(\mu \mathrm{g} / \mathrm{L})$ & 0.122 & 2.790 & 0.369 & 1.775 & $0.873 \pm 0.73$ \\
\hline
\end{tabular}

Table 3. According to the Spearmans Correlation analysis, the relationship between environmental parameters with each other in Kayalıköy reservoir

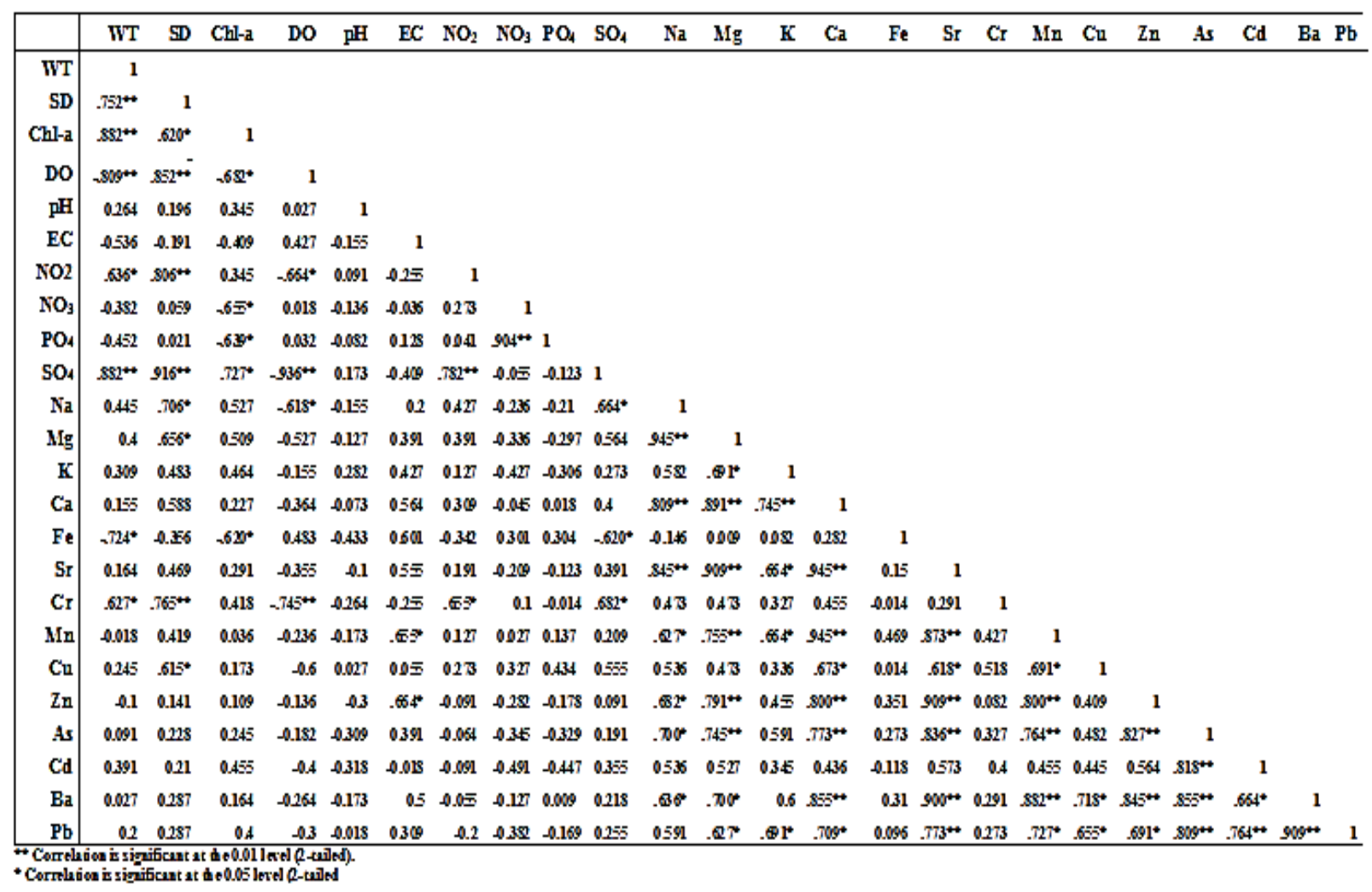




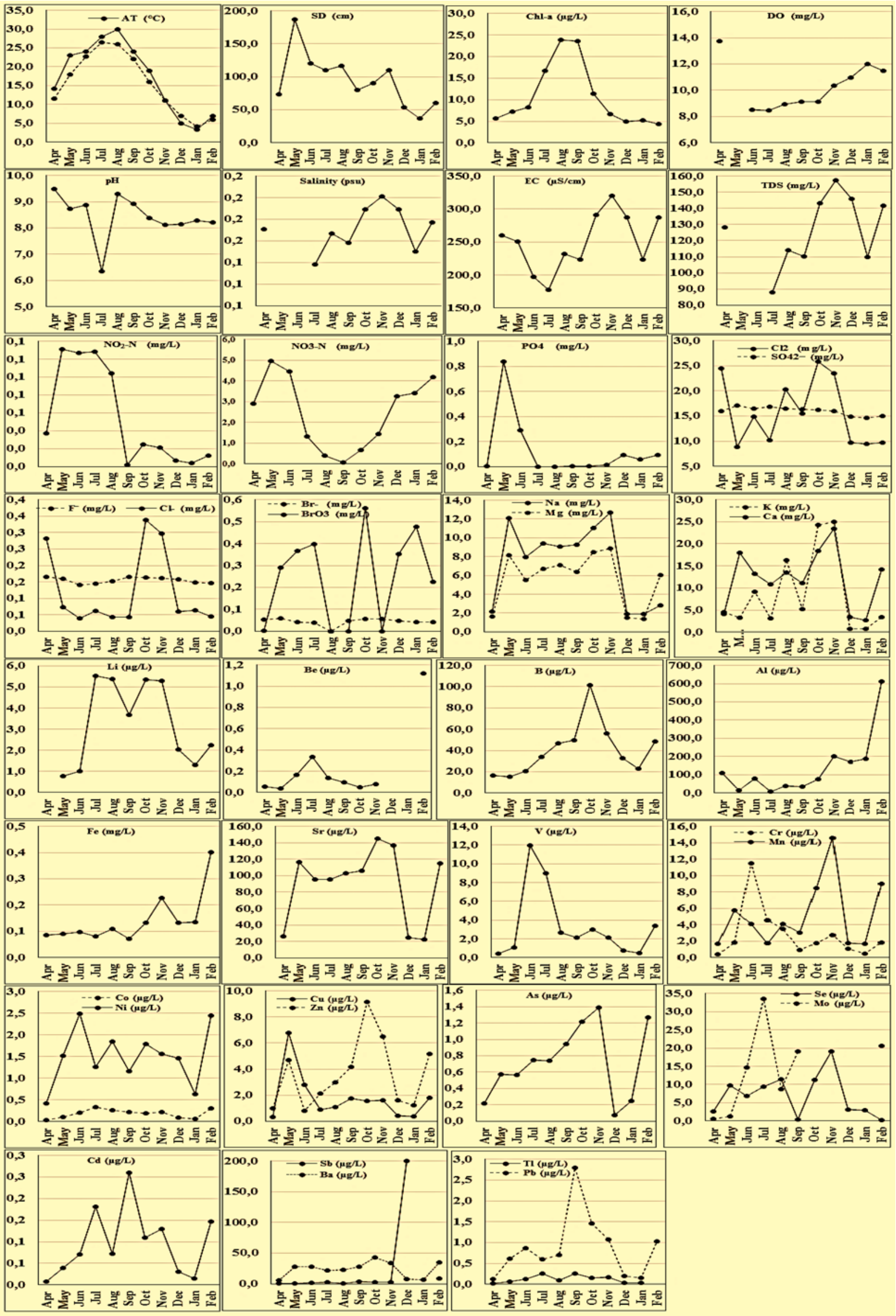

Figure 2. Variations of the physicochemical variables according to the sampling months 


\section{Discussion}

The water samples taken from three stations determined in Kayalıköy reservoir for one year were examined in terms of some physicochemical parameters and heavy metal concentrations. The results were compared with RSWQM (National Standart for Turkish inland water Regulation on Modification of Surface Water Quality Management) and RDWQ (Regulation on the Quality and Treatment of Water Provided for Drinking Water).

\section{Water temperature}

The highest and the lowest water temperature values were recorded as $26.500{ }^{\circ} \mathrm{C}$ in July in the summer season and $4.167^{\circ} \mathrm{C}$ in January in the winter season, respectively. The mean water temperature in the reservoir was $15.530 \pm 7.74^{\circ} \mathrm{C}$ (Table 2 and Figure 2). Water temperature affects the biological, chemical, and physical activities in water increases the metabolic and respiratory rates of aquatic organisms, and affects the dissolubility of gases. When the temperature increases, then the metabolic rate increases, and the level of oxygen decreases (Ünlü et al. 2008). These results indicate that the temperature differences between the months and the seasons were within acceptable levels for the survival of aquatic organisms. When the results of the physicochemical analysis were compared with RSWQM (2015), the water temperature in the reservoir was found to be Class I quality.

\section{Secchi disk depth}

Secchi disk in the reservoir was measured between 36.67-186.67 cm. Maximum light permeability was recorded in May in the spring season and the minimum in January in the winter season. The general mean Secchi disk depth in the reservoir was $94.24 \pm 39.34 \mathrm{~cm}$ (Table 2 and Figure 2 ). The lake is considered as eutrophic if the measured Secchi disk is between 0.8 and $1.5 \mathrm{~m}$, mesotrophic if it is between 1.4 and $2.4 \mathrm{~m}$, and oligotrophic if it is between 3.6 and $5.9 \mathrm{~m}$ (Ryding and Rast 1989). According to RSWQM (2015), the lake is considered as eutrophic if the measured Secchi disk is between 1.0 and $1.9 \mathrm{~m}$, mesotrophic if it is between 2.0 and $4.0 \mathrm{~m}$ and oligotrophic if it is $>4 \mathrm{~m}$. According to this classification based on Secchi disk depth, Kayalıköy reservoir could be categorized as eutrophic.

\section{Chlorophyll-a}

The highest and the lowest chlorophyll- $a$ values recorded as $23.833 \mu \mathrm{g} / \mathrm{L}$ in August in the summer season and $4.333 \mu \mathrm{g} / \mathrm{L}$ in February in the winter season, respectively. The mean chlorophyll- $a$ in the reservoir was $10.713 \pm 7.00 \mu \mathrm{g} / \mathrm{L}$ (Table 2 and Figure 2 ). For ponds and dam lakes, the amount of chlorophyll- $a$ in oligotrophic lakes is $<3.5 \mu \mathrm{g} / \mathrm{L}$, between 3.5-9.0 $\mu \mathrm{g} / \mathrm{L}$ in mesotrophic lakes and between $9.1-25 \mu \mathrm{g} / \mathrm{L}$ in eutrophic lakes (RSWQM 2015). The lake is considered as eutrophic if the average value of the measured chlorophyll-a 14.3 $\mu \mathrm{g} / \mathrm{L} ;$ mesotrophic if it is $4.7 \mu \mathrm{g} / \mathrm{L}$ and oligotrophic if it is $1.7 \mu \mathrm{g} / \mathrm{L}$ (Caspers 1984). According to the chlorophyll-a values in Kayalıköy reservoir could be classified as mesotrophic.

\section{Dissolved oxygen}

The maximum dissolved oxygen concentration was determined as $13.76 \mathrm{mg} / \mathrm{L}$ in April in the spring season and the minimum as $8.49 \mathrm{mg} / \mathrm{L}$ in July in the summer season with an annual average of $10.28 \pm 1.66$ $\mathrm{mg} / \mathrm{L}$ (Table 2 and Figure 2). Dissolved oxygen is one of the important parameters in water quality assessment and reflects the biological and physical processes that are common in water (Egemen and Sunlu 2006) and is inversely proportional to the water temperature (Öztürk and Akköz 2014). According to RSWQM (2015), Kayalıköy reservoir was Class I quality levels, which means it is clean water.

\section{pH}

$\mathrm{pH}$ is one of the important factors affecting living life in water. Many species of fish and aquatic organisms develop well in waters with a $\mathrm{pH}$ range of 6.5-8.5 (Arrignon 1976; Dauba 1981). In the present study, $\mathrm{pH}$ values in Kayalıköy reservoir were measured between 6.360 to 9.477 (average $8.435 \pm 0.79$ ). The maximum $\mathrm{pH}$ value was recorded in April in the spring season and the minimum in July in the summer season (Table 2 and Figure 2). The $\mathrm{pH}$ value of the lake was moderately alkaline varying from 7.5 to 8.2 (Berzins and Pejler 1987). According to the average $\mathrm{pH}$ values, Kayalıköy reservoir was rated as an alkaline water-bearing reservoir. Besides, according to RSWQM (2015) and RDWQ (2019) was Class I and Class A1 quality.

\section{Salinity}

Salinity is a dynamic indicator of the water ecosystem such as other parameters and it is expressed as the total concentration of charged ions in water. The salinity of the Kayalıköy reservoir was recorded as 0.138 psu in July in the summer season as the minimum and 0.201 psu in November in the autumn season as the maximum with the average value $0.171 \pm 0.02 \mathrm{psu}$ (Table 2 and Figure 2). According to salinity measurements, it was concluded that Kayalıköy Reservoir is suitable for aquatic life. While Salinity showed positive significant relationship with EC $(\mathrm{r}=858)$, TDS $(\mathrm{r}=998) \quad(\mathrm{p}<0.01)$ and $\mathrm{B} \quad(\mathrm{r}=648)$ $(\mathrm{p}<0.05)$, it showed negative relationship with $\mathrm{SO}_{4}$ $(\mathrm{r}=603)(\mathrm{p}<0.01)$. 


\section{Electrical conductivity}

The electrical conductivity of water depends on both geological factors and external influences (Barlas et al. 1995). Electrical conductivity in freshwater varies between $10-1000 \mu \mathrm{S} / \mathrm{cm}$. The acceptable electrical conductivity value for aquatic organisms is in the range of $250-500 \mu \mathrm{S} / \mathrm{cm}$ (Yücel 1990). The electrical conductivity in Kayalıköy reservoir was measured as $177.233-319.767 \mu \mathrm{S} / \mathrm{cm}$ (average $249.936 \pm 41.91 \mu \mathrm{S} / \mathrm{cm}$ ). The maximum electrical conductivity was recorded in November in the autumn season and the minimum in July in the summer season. According to RSWQM (2015) and RDWQ (2019), the reservoir water was assigned to have Class I and Class A1 quality and it was concluded that Kayalıköy reservoir is suitable for aquatic life. The Electrical conductivity (EC) showed a positive significant relationship with TDS ( $\mathrm{r}=847)$, Salinity $(\mathrm{r}=858) \quad(\mathrm{p}<0.01), \mathrm{Mn} \quad(\mathrm{r}=655)$ and $\mathrm{Zn}$ $(\mathrm{r}=664)(\mathrm{p}<0.05)($ Table 3$)$.

\section{Total dissolved solids matter}

The highest and the lowest total dissolved solids values were recorded as $157.200 \mathrm{mg} / \mathrm{L}$ in November in the autumn season and $8.010 \mathrm{mg} / \mathrm{L}$ in July in the summer season, respectively. The mean total dissolved solids in the reservoir was $126.395 \pm 21.09$ $\mathrm{mg} / \mathrm{L}$. (Table 2 and Figure 2). According to total dissolved solids measurements, it was concluded that Kayalıköy reservoir is suitable for aquatic life. While Total dissolved solids matter (TDS) showed a positive significant relationship with Salinity $(\mathrm{r}=998)$ and $\mathrm{B}(\mathrm{r}=620)$, it showed a negative relationship with $\mathrm{SO}_{4}(\mathrm{r}=620)(\mathrm{p}<0.05)$.

\section{Nitrite nitrogen and Nitrate nitrogen}

During the study period in Kayalıköy reservoir, the nitrite nitrogen concentration was 0.002-0.131 $\mathrm{mg} / \mathrm{L}$ (average $0.054 \pm 0.05$ ) and the minimum value was recorded in September in the winter season and the maximum in May in summer season (Table 2 and Figure 2). Nitrate nitrogen concentration was measured between 0.062 to $4.967 \mathrm{mg} / \mathrm{L}$ (average $2.458 \pm 1.67$ ) and the minimum value was recorded in September in the autumn season and the maximum in May in the spring season (Table 2 and Figure 2). Nitrogen derivatives such as nitrite $\left(\mathrm{NO}_{2}-\mathrm{N}\right)$ and nitrate $\left(\mathrm{NO}_{3}-\mathrm{N}\right)$ play an important role in the process of water pollution. The nitrite and nitrat sources in water are the organic matters, fertilizers used in agriculture, the wastewaters, and some minerals. The nitrite concentration in surface water higher than 1 $\mathrm{mg} / \mathrm{L}$ indicates the presence of pollution (Taş 2011). A high concentration of nitrate in surface waters indicates the pollution. According to RSWQM (2015), the total nitrogen content is $\leq 0.35 \mathrm{mg} / \mathrm{L}$ in oligotrophic lakes, $0.35-0.65 \mathrm{mg} / \mathrm{L}$ in mesotrophic lakes and 0.65-1.2 $\mathrm{mg} / \mathrm{L}$ in eutrophic lakes. According to the average nitrite nitrogen and nitrate nitrogen values, Kayalıköy reservoir was rated as oligotrophic and Class I. The Nitrite nitrogen $\left(\mathrm{NO}_{2-}\right.$ $\mathrm{N})$ showed a positive significant relationship with $\mathrm{SD}$ $(\mathrm{r}=806), \mathrm{SO}_{4}(\mathrm{r}=782)(\mathrm{p}<0.01)$, WT $(\mathrm{r}=636)$ and $\mathrm{Cr}$ $(\mathrm{r}=655)(\mathrm{p}<0.05)$, it showed a negative relationship with DO $(r=664)(p<0.01)$. Also, While Nitrate nitrogen $\left(\mathrm{NO}_{3}-\mathrm{N}\right)$ showed positive significant relationship with $\mathrm{PO}_{4}(\mathrm{r}=904)(\mathrm{p}<0.05)$, it showed negative relationship with Chl $-a(\mathrm{r}=655), \mathrm{Cl}_{2}(\mathrm{r}=645)$ and $B(r=673)(p<0.05)($ Table 3$)$.

\section{Phosphate}

Phosphate concentrations fluctuated during the study from 0.000 to $0.839 \mathrm{mg} / \mathrm{L}$ (average $0.126 \pm 0.24$ $\mathrm{mg} / \mathrm{L}$ ). The maximum phosphate concentration was recorded in May in the spring season and the minimum in July, August in the autumn season (Table 2 and Figure 2). Phosphate concentration was below the detection limit during these months. If the total phosphorus is less than $10 \mu \mathrm{g} / \mathrm{L}$, the lake is oligotrophic, if between $10-20 \mu \mathrm{g} / \mathrm{L}$ it is mesotrophic and if it is greater than $20 \mu \mathrm{g} / \mathrm{L}$, it is eutrophic (Thoman and Mueller 1987). RSWQM (2015) reported that phosphate concentration is $00.01 \mathrm{mg} / \mathrm{L}$ in oligotrophic lakes, $0.01-0.03 \mathrm{mg} / \mathrm{L}$ in mesotrophic lakes and $0.03-0.1 \mathrm{mg} / \mathrm{L}$ in eutrophic lakes. RDWQ (2019) reported the concentration of phosphate as 0.4 $\mathrm{mg} / \mathrm{L}$ in Class A1 and $0.7 \mathrm{mg} / \mathrm{L}$ in Class A2. Based on these results, Kayalıköy reservoir was rated as oligotrophic and Class I and A1. While Phosphate $\left(\mathrm{PO}_{4}\right)$ showed positive significant relationship with $\mathrm{NO}_{3}(\mathrm{r}=904)$ and $\mathrm{K}(\mathrm{r}=809)(\mathrm{p}<0.01)$, it showed negative relationship with Chl- $a(\mathrm{r}=639) \quad(\mathrm{p}<0.05)$ (Table 3).

\section{Chlorine}

The values of chlorine fluctuated during the study from 8.859 to $25.767 \mathrm{mg} / \mathrm{L}$ (average $15.675 \pm 6.38$ $\mathrm{mg} / \mathrm{L}$ ). The maximum value of chlorine was recorded in October in the autumn season and the minimum in May in the winter season. (Table 2 and Figure 2). Considering the taste threshold for chlorine in drinking water is below $5 \mathrm{mg} / \mathrm{L}$ (WHO 2017), the chlorine value is high in the reservoir. Therefore, care must be taken during the disinfection of water. While Chlorine $\left(\mathrm{Cl}_{2}\right)$ showed positive significant relationship with $\mathrm{Na} \quad(\mathrm{r}=664)$ and $\mathrm{Cr} \quad(\mathrm{r}=682)$ $(\mathrm{p}<0.05)$, it showed negative relationship with $\mathrm{Al}$ $(\mathrm{r}=827) \quad(\mathrm{p}<0.05), \mathrm{NO}_{3}(\mathrm{r}=645)$ and $\mathrm{Fe}(\mathrm{r}=620)$ $(\mathrm{p}<0.05)$.

\section{Sulfate}

Sulphate concentration in the reservoir was measured between 14.665-7.076 mg/L. The maximum value of sulfate was recorded in May in the spring season and the minimum in January in the 
winter season. The mean value of sulfate in the reservoir was $15.999 \pm 0.78 \mathrm{mg} / \mathrm{L}$ (Table 2 and Figure 2). The sulfate $\left(\mathrm{SO}_{4}^{-2}\right)$ among natural anions of waters should exist in natural waters for biological productivity to increase (Taş et al. 2010). The level of sulfate in natural waters varies between 5 and 100 $\mathrm{mg} / \mathrm{L}$. The maximum sulfate level required for aquatic products is $90 \mathrm{mg} / \mathrm{L}$ and it is more than 250 $\mathrm{mg} / \mathrm{L}$ indicates serious pollution (Nisbet and Verneaux 1970). RDWQ (2019) reported the concentration of sulfate as $250 \mathrm{mg} / \mathrm{L}$ in Class A1 and $1250 \mathrm{mg} / \mathrm{L}$ in Class A3 waters. According to these results, Kayalıköy reservoir has clean water characteristics and Class A2. While Sulphate $\left(\mathrm{SO}_{4}\right)$ showed positive significant relationship with WT $(\mathrm{r}=882), \mathrm{SD}(\mathrm{r}=916), \mathrm{NO}_{2}(\mathrm{r}=782)(\mathrm{p}<0.01), \mathrm{Chl}-\mathrm{a}$ $(\mathrm{r}=727), \mathrm{Na}(\mathrm{r}=664)$ and $\mathrm{Cr}(\mathrm{r}=682)(\mathrm{p}<0.05)$, it showed negative relationship with DO $(\mathrm{r}=936), \mathrm{Al}$ $(\mathrm{r}=827)(\mathrm{p}<0.01)$, Salinity $(\mathrm{r}=603)$ and $\mathrm{Fe}(\mathrm{r}=620)$ $(\mathrm{p}<0.05)$ (Table 3).

\section{Fluoride}

The presence of fluoride in drinking water at certain concentrations is important for bone and dental health. In the present study, fluoride values in Kayal1köy reservoir were measured between 0.140 $0.166 \mathrm{mg} / \mathrm{L}$ (average $0.155 \pm 0.01 \mathrm{mg} / \mathrm{L}$ ). The maximum fluoride value was recorded in April in the autumn season and the minimum in June in the summer season (Table 2 and Figure 2). The optimum concentration of fluoride is $1 \mathrm{mg} / \mathrm{L}$, but regulations allow a maximum concentration of $1.5 \mathrm{mg} / \mathrm{L}$ in drinking water. If fluoride concentration is less than $1000 \mu \mathrm{g} / \mathrm{L}$ the water is Class I if between $1500 \mu \mathrm{g} / \mathrm{L}$ it is Class II and if it is $2000 \mu \mathrm{g} / \mathrm{L}$, it is Class III. (RSWQM 2015). RDWQ (2019) reported the concentration fluoride as $>200 \mu \mathrm{g} / \mathrm{L}$ in Class A1, $5000 \mu \mathrm{g} / \mathrm{L}$ Class A2, and $7500 \mu \mathrm{g} / \mathrm{L}$ in Class A3. According to these results, Kayalıköy reservoir has been water Class II and A1. While Fluoride (F) showed positive significant relationship with $\mathrm{Br}$ $(\mathrm{r}=663) \quad(\mathrm{p}<0.01)$, it showed negative relationship with $\mathrm{Cr}(\mathrm{r}=638)(\mathrm{p}<0.05)$.

\section{Chloride}

The chloride which exists in all natural waters is an important component of natural waters, and affects the distribution, diversity, and abundance of organisms in water. In the present study, chloride value in Kayalıköy reservoir was measured between $0.040-0.338 \mathrm{mg} / \mathrm{L}$ (average $0.122 \pm 0.11 \mathrm{mg} / \mathrm{L}$ ). The maximum chloride value was recorded in October in the autumn season and the minimum in June in the summer season (Table 2 and Figure 2). Chloride ion is present in natural waters at a rate of $0-30 \mathrm{mg} / \mathrm{L}$, while it is present at concentrations of $0.2-1 \mathrm{mg} / \mathrm{L}$ in disinfected drinking water (White 1978). According to these data, Kayalıköy reservoir is suitable for aquaculture, drinking, and domestic water. While Chloride $(\mathrm{Cl})$ showed positive significant relationship with $\mathrm{Br}(\mathrm{r}=645)(\mathrm{p}<0.01)$, it showed negative relationship with Mo $(\mathrm{r}=620)(\mathrm{p}<0.05)$.

\section{Bromide}

The ionic form, bromide, $\mathrm{Br}^{-}$, is generally found in a variety of salts and is highly soluble in water. Bromide salts are more soluble than chloride salts, thus evaporation induced precipitation produces solids that are enriched in chloride and residual brines that are enriched in bromide. Bromide is rarely observed at significant concentrations in surface freshwater systems and its concentration is between 0.014-0.2 mg/L (Bowen 1979). RDWQ (2019) reported the concentration of bromide as $2000 \mu \mathrm{g} / \mathrm{L}$ in Class A1, $4000 \mu \mathrm{g} / \mathrm{L}$ in Class A2, and $6500 \mu \mathrm{g} / \mathrm{L}$ in Class A3. In the present study, the bromide value was detected the maximum $0.059 \mathrm{mg} / \mathrm{L}$ and the minimum $0.000 \mathrm{mg} / \mathrm{L}$. The maximum bromide value was recorded in May in the spring season the minimum in August in the summer season. It was below the detection limits this month (Table 2 and Figure 2). The average of bromide concentration in the reservoir was measured as $0.044 \pm 0.02 \mathrm{mg} / \mathrm{L}$ in the reservoir. In terms of bromide values, the Kayalıköy reservoir is suitable for drinking and domestic water and Class A1 water.

\section{Bromate}

Bromate is an inorganic ion. It is not normally present in water but enters the water as disinfection by-product that occurs when the naturally occurring bromide ion reacts with ozone $\left(\mathrm{O}_{3}\right)$. The concentration of the bromate was reported as 2.9 $\mu \mathrm{g} / \mathrm{L}$ with a range of $<0.2-25 \mu \mathrm{g} / \mathrm{L}$ for surface water sources (WHO 2008). RDWQ (2019) reported the concentrations of bromate as $10 \mu \mathrm{g} / \mathrm{L}$ in Class A1, 12 $\mu \mathrm{g} / \mathrm{L}$ in Class $\mathrm{A} 2$, and $100 \mu \mathrm{g} / \mathrm{L}$ in Class A3. In the present study, bromate values in Kayalıköy reservoir were measured between $0.000-0.243 \mathrm{mg} / \mathrm{L}$ (average $0.243 \pm 0.20 \mathrm{mg} / \mathrm{L}$ ). The maximum bromate value was recorded in October in the winter season and the minimum in August in the spring season. The bromate concentration was below the detection limit in August (Table 2 and Figure 2). In terms of bromate average values, the Kayalıköy reservoir has Class A3 water which is not suitable for drinking purposes.

\section{Sodium}

Sodium concentrations fluctuated during the study from 1.894 to $12.695 \mathrm{mg} / \mathrm{L}$ (average $7.304 \pm 4.08 \mathrm{mg} / \mathrm{L}$ ). The maximum sodium concentration was recorded in November in the autumn season and the minimum in December in the winter season (Table 2 and Figure 2). The sodium ion is ubiquitous in water. Most water supplies contain 
less than $20 \mathrm{mg} / \mathrm{L}$ but in some countries, levels can exceed $250 \mathrm{mg} / \mathrm{L}$. Sodium salt concentration varies between $2-100 \mathrm{mg} / \mathrm{L}$ in natural waters (Tepe 2009). RDWQ (2019) reported the concentration of sodium as $200 \mathrm{mg} / \mathrm{L}$ in Class A1 and $2000 \mathrm{mg} / \mathrm{L}$ in Class A3. In terms of sodium average values, the Kayalıköy reservoir has Class A1 water which is suitable for drinking purposes. While Sodium $(\mathrm{Na})$ showed positive significant relationship with $\mathrm{Mg}(\mathrm{r}=945), \mathrm{Ca}$ $(\mathrm{r}=809), \mathrm{Sr} \quad(\mathrm{r}=845) \quad(\mathrm{p}<0.01), \mathrm{SD} \quad(\mathrm{r}=706), \mathrm{SO}_{4}$ $(\mathrm{r}=664), \mathrm{Mn}(\mathrm{r}=627), \mathrm{Zn}(\mathrm{r}=682)$, As $(\mathrm{r}=700)$, Se $(\mathrm{r}=655), \mathrm{Ba}(\mathrm{r}=636)$ and $\mathrm{Tl}(\mathrm{r}=664)(\mathrm{p}<0.05)$, it showed negative relationship with DO $(\mathrm{r}=618)$ $(\mathrm{p}<0.05)$ (Table 3$)$.

\section{Magnesium}

Magnesium is one of the ions that make up the hardness of the water. Because magnesium is present in the composition of chlorophyll, it is vital for chlorophyll plants and found in the in natural waters as $10-50 \mathrm{mg} / \mathrm{L}$. In the present study, magnesium value was detected the maximum $8.899 \mathrm{mg} / \mathrm{L}$ in November and the minimum $1.349 \mathrm{mg} / \mathrm{L}$ in January. The average magnesium values was determined as $5.613 \pm 2.71 \mathrm{mg} / \mathrm{L}$ in the reservoir (Table 2 and Figure 2). According to these data, Kayalıköy reservoir is suitable for drinking and domestic water. The Magnesium (Mg) showed positive significant relationship with $\mathrm{Na}(\mathrm{r}=945), \mathrm{Ca}(\mathrm{r}=891), \mathrm{Sr}(\mathrm{r}=909)$, Mn ( $\mathrm{r}=755), \mathrm{Zn}(\mathrm{r}=791)$, As $(\mathrm{r}=745)(\mathrm{p}<0.01)$, SD $(\mathrm{r}=656), \mathrm{K}(\mathrm{r}=691)$, Se $(\mathrm{r}=727)$ and $\mathrm{Pb}(\mathrm{r}=627)$ $(\mathrm{p}<0.05)$ (Table 3).

\section{Potassium}

Potassium is one of the inorganic salts that give water taste. Potassium is found in the natural waters between $1-10 \mathrm{mg} / \mathrm{L}$ (Tepe 2009). In the present study, the average potassium value was determined as $8.691 \pm 8.58 \mathrm{mg} / \mathrm{L}$ in the reservoir. The potassium value was detected the maximum $25.019 \mathrm{mg} / \mathrm{L}$ in November in the autumn season and the minimum $0.718 \mathrm{mg} / \mathrm{L}$ in January in the winter season (Table 2 and Figure 2). According to these data, Kayalıköy reservoir is suitable for drinking, agricultural irrigation, and aquaculture. The Potassium (K) showed positive significant relationship with $\mathrm{Cl}_{2}$ $(\mathrm{r}=809), \quad \mathrm{Ca} \quad(\mathrm{r}=745) \quad(\mathrm{p}<0.01) \quad \mathrm{Mg} \quad(\mathrm{r}=691), \quad \mathrm{Sr}$ $(\mathrm{r}=664), \mathrm{Mn} \quad(\mathrm{r}=664)$ and $\mathrm{Pb} \quad(\mathrm{r}=691) \quad(\mathrm{p}<0.05)$ (Table 3).

\section{Calcium}

Calcium is an important determinant of water hardness, and it also functions as a $\mathrm{pH}$ stabilizer because of its buffering qualities. Calcium also gives water a better taste. When the amount of calcium in water is about $25 \mathrm{mg} / \mathrm{L}$, the productivity increases to a maximum but below $12 \mathrm{mg} / \mathrm{L}$ the productivity decreases (Bremond and Vuichard 1973; Nisbet and
Verneaux 1970). While the amount of calcium suitable for fishing is $30-40 \mathrm{mg} / \mathrm{L}$, it can reach natural waters to a value of $150 \mathrm{mg} / \mathrm{L}$. In the present study, the maximum calcium concentration was measured as $23.479 \mathrm{mg} / \mathrm{L}$ in November in the autumn season and the minimum as $2.646 \mathrm{mg} / \mathrm{L}$ in January in the winter season. The average calcium concentration in the reservoir was measured as $12.060 \pm 6.34 \mathrm{mg} / \mathrm{L}$ (Table 2 and Figure 2). According to these data, Kayalıköy reservoir is suitable for drinking, agricultural irrigation, and aquaculture. The Calcium (Ca) showed positive significant relationship with $\mathrm{Na}$ $(\mathrm{r}=809), \mathrm{Mg}(\mathrm{r}=891), \mathrm{K}(\mathrm{r}=745), \mathrm{Sr}(\mathrm{r}=945), \mathrm{Mn}$ $(\mathrm{r}=945), \quad \mathrm{Zn} \quad(\mathrm{r}=800), \quad$ As $(\mathrm{r}=773), \mathrm{Ba} \quad(\mathrm{r}=855)$ $(\mathrm{p}<0.01), \mathrm{Ni}(\mathrm{r}=659), \mathrm{Cu}(\mathrm{r}=673)$ and $\mathrm{Pb}(\mathrm{r}=709)$ $(\mathrm{p}<0.05)$ (Table 3).

\section{Lithium}

Seawater contains approximately $0.17 \mathrm{ppm}$ lithium. Rivers generally contain only $3 \mathrm{ppb}$, whereas mineral water contains $0.05-1 \mathrm{mg} / \mathrm{L}$. The lithium reacts with water, forming lithium hydroxide and hydrogen. The lithium concentration in Kayalıköy reservoir was measured between 0.773-5.530 $\mu \mathrm{g} / \mathrm{L}$. The maximum lithium value was recorded in July in the autumn season and the minimum in May in the spring season. The average of lithium values was determined as $3.261 \pm 1.89 \mu \mathrm{g} / \mathrm{L}$ in Kayalıköy reservoir (Table 2 and Figure 2).

\section{Beryllium}

Beryllium values were detected as $1.120 \mu \mathrm{g} / \mathrm{L}$ in February in the winter season as the maximum and $0.035 \mu \mathrm{g} / \mathrm{L}$ in May in the spring season as the minimum. The average of beryllium concentration was determined as $0.230 \pm 0.33 \mu \mathrm{g} / \mathrm{L}$ in the reservoir (Table 2 and Figure 2). There are only limited data on beryllium concentrations in water except the USA. The concentration of beryllium in surface waters has been reported as $0.001 \mathrm{mg} / \mathrm{L}$ by USEPA (2002). According to these data, it can be said that Kayalıöy reservoir contains beryllium under the limit values.

\section{Boron}

Boron concentration in Kayal1köy reservoir was measured as 15.236-101.169 $\mu \mathrm{g} / \mathrm{L}$ (average $40.342 \pm 23.61 \mu \mathrm{g} / \mathrm{L}$ ). The maximum boron value was recorded in October in the autumn season and the minimum in May in the spring season (Table 2 and Figure 2). The amount of boron in freshwater depends on such factors as the geochemical nature of the drainage area, proximity to marine coastal regions, and inputs from industrial and municipal effluents (Butterwick et al. 1989). Boron concentrations in fresh surface water range from $<0.001$ to $2 \mathrm{mg} / \mathrm{L}$ in Europe, with mean values typically below $0.6 \mathrm{mg} / \mathrm{L}$. Similar concentration ranges have been reported for water bodies within 
Pakistan, Russia, and Turkey, from 0.01 to $7 \mathrm{mg} / \mathrm{L}$, with most values below $0.5 \mathrm{mg} / \mathrm{L}$ (WHO 1998). RSWQM (2015) reported the concentration of boron as $\leq 1000 \mu \mathrm{g} / \mathrm{L}$ in Class I, II, III, and $>1000 \mu \mathrm{g} / \mathrm{L}$ in Class IV waters. RDWQ (2019) reported the concentration of bromate as $>1000 \mu \mathrm{g} / \mathrm{L}$ in Class A1, $1250 \mu \mathrm{g} / \mathrm{L}$ in Class A2, and $5000 \mu \mathrm{g} / \mathrm{L}$ in Class A3 waters. According to these data, Kayalıköy reservoir is suitable for drinking, agricultural irrigation, and aquaculture.

\section{Aluminum}

The maximum and the minimum aluminum values were determined as $612.883 \mu \mathrm{g} / \mathrm{L}$ and 6.475 $\mu \mathrm{g} / \mathrm{L}$ in February in the winter season and in July in the summer season, respectively, and the average was determined as $139.261 \pm 163.34 \mu \mathrm{g} / \mathrm{L}$ (Table 2 and Figure 2). The concentration of aluminum in natural waters can significantly depend on various physicochemical factors. Dissolved aluminum concentrations in waters with near-neutral $\mathrm{pH}$ values usually range from 0.001 to $0.05 \mathrm{mg} / \mathrm{L}$ (WHO 1998). For ponds and dam lakes, the aluminum concentration is $\leq 0.3 \mathrm{mg} / \mathrm{L}$ in Class I and Class II, 0.3 $\mathrm{mg} / \mathrm{L}$ in Class III, and $>1 \mathrm{mg} / \mathrm{L}$ in Class IV waters (RSWQM 2015). RDWQ (2019) reported the concentrations of aluminum as is $200 \mu \mathrm{g} / \mathrm{L}$ in Class $\mathrm{A} 1,500 \mu \mathrm{g} / \mathrm{L}$ in Class A2, and $2000 \mu \mathrm{g} / \mathrm{L}$ in Class A3 waters. According to these results, Kayalıköy reservoir has Class II and A1 water and is suitable for drinking, agricultural irrigation, and aquaculture. While Aluminium (Al) showed positive significant relationship with $\mathrm{DO}(\mathrm{r}=791)$ and $\mathrm{Fe}(\mathrm{r}=834)$, it showed negative relationship with WT $(\mathrm{r}=845)$, Chl$a(\mathrm{r}=791)$ and $\mathrm{SO}_{4}(\mathrm{r}=827)(\mathrm{p}<0.01)$.

\section{Iron}

Iron concentrations fluctuated during the study from 0.072 to $0.401 \mathrm{mg} / \mathrm{L}$ (average $0.142 \pm 0.09$ $\mathrm{mg} / \mathrm{L}$ ). The maximum iron concentration was recorded in February in the winter season and the minimum in September in the spring season (Table 2 and Figure 2). Iron concentrations in drinking water are normally less than $0.3 \mathrm{mg} / \mathrm{L}$ but may be higher in some countries (WHO 1998). For ponds and dam lakes, the iron concentration is $\leq 300 \mu \mathrm{g} / \mathrm{L}$ in Class I, $1000 \mu \mathrm{g} / \mathrm{L}$ in Class II, 5000 in Class III, and >5000 $\mu \mathrm{g} / \mathrm{L}$ in Class IV waters (RSWQM 2015). Also, RDWQ (2019) reported the concentration of iron as $2000 \mu \mathrm{g} / \mathrm{L}$ in Class A1, $1000 \mu \mathrm{g} / \mathrm{L}$ in Class A2 and $2000 \mu \mathrm{g} / \mathrm{L}$ in Class A3 waters. According to these results, Kayalıköy reservoir has Class I and A1 water and is suitable for drinking, agricultural irrigation, and aquaculture. While Iron $(\mathrm{Fe})$ showed positive significant relationship with $\mathrm{Al}(\mathrm{r}=834)(\mathrm{p}<0.01)$, it showed negative relationship with WT $(\mathrm{r}=724)$, Chl$a(\mathrm{r}=620)$ and $\mathrm{SO}_{4}(\mathrm{r}=620)(\mathrm{p}<0.05)($ Table 3$)$.

\section{Strontium}

Because strontium is naturally occurring throughout the earth, it shas detected in all surface waters. The maximum acceptable concentration of $7.0 \mathrm{mg} / \mathrm{L}$ is proposed for total strontium in drinking water (FPTC 2018). The US Environmental Protection Agency (EPA) recommends the concentration of strontium in drinking water as 4 $\mathrm{mg} / \mathrm{L}$ (NWQMC 2016). In the present study, strontium value was detected the maximum 144.727 $\mu \mathrm{g} / \mathrm{L}$ and the minimum $22.133 \mu \mathrm{g} / \mathrm{L}$. The average concentration of strontium was determined as $89.538 \pm 42.51 \mu \mathrm{g} / \mathrm{L}$ in the reservoir. The maximum of the strontium concentration was recorded in October in the autumn season and the minimum in January in the winter season (Table 2 and Figure 2). According to these results, Kayalıköy reservoir is suitable for drinking, agricultural irrigation, and aquaculture. While strontium $(\mathrm{Sr})$ showed positive significant relationship with $\mathrm{Na}(\mathrm{r}=845), \mathrm{Mg} \quad(\mathrm{r}=909), \mathrm{Ca}$ $(\mathrm{r}=945), \mathrm{Mn}(\mathrm{r}=873), \mathrm{Zn}(\mathrm{r}=909)$, As ( $\mathrm{r}=836), \mathrm{Ba}$ $(\mathrm{r}=900), \mathrm{Pb}(\mathrm{r}=773)(\mathrm{p}<0.01), \mathrm{K}(\mathrm{r}=664)$ and $\mathrm{Cu}$ $(\mathrm{r}=618)(\mathrm{p}<0.05)$.

\section{Vanadium}

Vanadium is an element in general of volcanic origin. Italian Ministry of Health has determined for in drinking water a value which does not exceed 140 $\mathrm{mg} / \mathrm{L}$. The California Office of Environmental Health Hazard Assessment proposed a notification level of $15 \mu \mathrm{g} / \mathrm{L}$ in drinking water (USEPA 2008). RDWQ (2019) reported the concentration of vanadium as is $15 \mu \mathrm{g} / \mathrm{L}$ in Class $\mathrm{A} 1,50 \mu \mathrm{g} / \mathrm{L}$ in Class $\mathrm{A} 2$, and $150 \mu \mathrm{g} / \mathrm{L}$ in Class $\mathrm{A} 3$ waters. In the present study, vanadium values were detected the maximum $11.978 \mu \mathrm{g} / \mathrm{L}$ and the minimum $0.391 \mu \mathrm{g} / \mathrm{L}$. The average values of vanadium were determined by $3.362 \pm 3.55 \mu \mathrm{g} / \mathrm{L}$ in the reservoir. The maximum of the vanadium value was recorded in July in summer season and the minimum in April in the spring season (Table 2 and Figure 2). Based on these results, Kayalıköy reservoir is suitable for drinking, agricultural irrigation, and aquaculture. The vanadium (V) showed positive significant relationship with $\mathrm{Be}(\mathrm{r}=779), \mathrm{Cr}(\mathrm{r}=818), \mathrm{Co}(\mathrm{r}=773)$, $\mathrm{Ni} \quad(\mathrm{r}=755) \quad(\mathrm{p}<0.01)$ and $\mathrm{Cd} \quad(\mathrm{r}=645) \quad(\mathrm{p}<0.05)$ (Table 3).

\section{Chromium:}

The values of chromium fluctuated during the study from 0.408 to $11.465 \mu \mathrm{g} / \mathrm{L}$ (average $2.786 \pm 3.00$ $\mu \mathrm{g} / \mathrm{L}$ ) in the reservoir. The maximum chromium values were recorded in June in the summer season and the minimum in April in the spring season. (Table 2 and Figure 2). The total chromium content of surface waters is approximately $0.5-2 \mu \mathrm{g} / \mathrm{L}$ and the dissolved chromium content $0.02-0.3 \mu \mathrm{g} / \mathrm{L}$ 
(Slooff 1989). The chromium concentration varies between 0.1-117 $\mu \mathrm{g} / \mathrm{L}$ in freshwaters (Shanker et al. 2005). For ponds and dam lakes, the total chromium content is is $\leq 20 \mu \mathrm{g} / \mathrm{L}$ in Class I, $20 \mu \mathrm{g} / \mathrm{L}$ in Class II, $50 \mu \mathrm{g} / \mathrm{L}$ in Class III, and $>50 \mu \mathrm{g} / \mathrm{L}$ in Class IV waters (RSWQM 2015). RDWQ (2019) reported the concentration of chromium as is $50 \mu \mathrm{g} / \mathrm{L}$ in Class A1, $500 \mu \mathrm{g} / \mathrm{L}$ in Class A2, and $1000 \mu \mathrm{g} / \mathrm{L}$ in Class A3 waters. According to these results, Kayal1köy reservoir has water Class I and A1 and is suitable for drinking, agricultural irrigation, and aquaculture. The Chromium (Cr) showed positive significant relationship with SD $(\mathrm{r}=765), \mathrm{V}(\mathrm{r}=818)(\mathrm{p}<0.01)$, WT (r=627), $\mathrm{NO}_{2}(\mathrm{r}=655) \mathrm{SO}_{4}(\mathrm{r}=682) \mathrm{E}(\mathrm{r}=638), \mathrm{Co}$ $(\mathrm{r}=645)$ and $\mathrm{Ni}(\mathrm{r}=709)(\mathrm{p}<0.05)$.

\section{Manganese}

The maximum manganese concentration was determined as $14.601 \mu \mathrm{g} / \mathrm{L}$ in November in the autumn season and the minimum as $1.659 \mu \mathrm{g} / \mathrm{L}$ in January in winter season with an annual average of $5.078 \pm 3.93 \mu \mathrm{g} / \mathrm{L}$ (Table 2 and Figure 2). Maganese which is one of the ions responsible for the hardness of water is present in natural waters with concentrations ranging from 10 to $50 \mathrm{mg} / \mathrm{L}$. Manganese concentration in freshwater is typically 1 to $200 \mu \mathrm{g} / \mathrm{L}$ (Barceloux 1999). For ponds and dam lakes, the manganese concentration is $\leq 100 \mu \mathrm{g} / \mathrm{L}$ in Class I, $500 \mu \mathrm{g} / \mathrm{L}$ in Class II, $3000 \mu \mathrm{g} / \mathrm{L}$ in Class III and $>3000 \mu \mathrm{g} / \mathrm{L}$ in Class IV waters (RSWQM 2015). RDWQ (2019) reported the concentration of manganese as $50 \mu \mathrm{g} / \mathrm{L}$ in Class $\mathrm{A} 1,100 \mu \mathrm{g} / \mathrm{L}$ in Class $\mathrm{A} 2$, and $250 \mu \mathrm{g} / \mathrm{L}$ in Class A3 waters. According to these results, Kayalıköy reservoir has Class I and A1 water and is suitable for drinking, agricultural irrigation, and aquaculture. The Manganese (Mn) showed positive significant relationship with $\mathrm{Mg}$ $(\mathrm{r}=755), \mathrm{Ca}(\mathrm{r}=945), \mathrm{Sr} \quad(\mathrm{r}=873, \mathrm{Ni} \quad(\mathrm{r}=736), \mathrm{Zn}$ $(\mathrm{r}=800), \mathrm{Ba}(\mathrm{r}=882) \quad(\mathrm{p}<0.01), \mathrm{EC} \quad(\mathrm{r}=655), \mathrm{Na}$ $(\mathrm{r}=627), \mathrm{K}(\mathrm{r}=664) \mathrm{Cu}(\mathrm{r}=691)$ and $\mathrm{Pb}(\mathrm{r}=727)$ $(\mathrm{p}<0.05)($ Table 3$)$.

\section{Cobalt}

The values of cobalt fluctuated during the study from 0.039 to $0.333 \mu \mathrm{g} / \mathrm{L}$ (average $0.186 \pm 0.09 \mu \mathrm{g} / \mathrm{L}$ ) in the reservoir. The maximum values of cobalt were recorded in July in the summer season and the minimum in April in the spring season (Table 2 and Figure 2). The cobalt concentrations in drinking water are generally $<1-2 \mu \mathrm{g} / \mathrm{L}$ (WHO 2008). RSWQM (2015) reported the concentration of cobalt as is $\leq 10 \mu \mathrm{g} / \mathrm{L}$ in Class I, $20 \mu \mathrm{g} / \mathrm{L}$ in Class II, 200 $\mu \mathrm{g} / \mathrm{L}$ in Class III and $>200 \mu \mathrm{g} / \mathrm{L}$ in Class IV waters. RDWQ (2019) reported the concentration of cobalt as is $800 \mu \mathrm{g} / \mathrm{L}$ in Class A1 and $2600 \mu \mathrm{g} / \mathrm{L}$ in Class A3 waters. In terms of the cobalt values, Kayalıköy reservoir has Class I and A1 water and is suitable for drinking, agricultural irrigation, and aquaculture. The Cobalt (Co) showed positive significant relationship with Be ( $\mathrm{r}=843), \mathrm{V}(\mathrm{r}=773)$, Mo ( $\mathrm{r}=740), \mathrm{Cd}(\mathrm{r}=882)$ $(\mathrm{p}<0.01), \mathrm{Cr}(\mathrm{r}=645)$ and As $(\mathrm{r}=691)(\mathrm{p}<0.05)$.

\section{Nickel}

The maximum and the minimum nickel concentrations were determined as $2.485 \mu \mathrm{g} / \mathrm{L}$ and as $0.418 \mu \mathrm{g} / \mathrm{L}$ in June in summer season and the minimum in April in the spring season, respectively, with an annual average of $1.509 \pm 0.62 \mu \mathrm{g} / \mathrm{L}$ (Table 2 and Figure 2). RSWQM (2015) reported the concentration of nickel as $\leq 20 \mu \mathrm{g} / \mathrm{L}$ in Class I, 50 $\mu \mathrm{g} / \mathrm{L}$ in Class II, $200 \mu \mathrm{g} / \mathrm{L}$ in Class III and $>200 \mu \mathrm{g} / \mathrm{L}$ in Class IV waters. Besides, RDWQ (2019) reported the concentration of nickel as $20 \mu \mathrm{g} / \mathrm{L}$ in Class $\mathrm{A} 1$, $30 \mu \mathrm{g} / \mathrm{L}$ in Class $\mathrm{A} 2$, and $200 \mu \mathrm{g} / \mathrm{L}$ in Class A3 waters. According to these results, Kayalıköy reservoir has Class I and A1 water and is suitable for drinking, agricultural irrigation, and aquaculture. The Nickel (Ni) showed positive significant relationship with V ( $\mathrm{r}=755), \mathrm{Mn}(\mathrm{r}=736)(\mathrm{p}<0.01), \mathrm{Ca}(\mathrm{r}=636), \mathrm{Cr}$ $(\mathrm{r}=709), \mathrm{Cu}(\mathrm{r}=655)$ and $\mathrm{Ba}(\mathrm{r}=618)(\mathrm{p}<0.05)$.

\section{Copper}

The values of copper fluctuated during the study from 0.348 to $6.796 \mu \mathrm{g} / \mathrm{L}$ (average $1.769 \pm 1.74 \mu \mathrm{g} / \mathrm{L}$ ). The maximum value of copper was recorded in May in the spring season and the minimum in April in the winter season (Table 2 and Figure 2). The copper concentrations in surface waters ranged from 0.0005 to $1 \mathrm{mg} / \mathrm{L}$ in several studies in the USA (average 0.01 $\mathrm{mg} / \mathrm{L}$ ) (ATSDR 2002). RSWQM (2015) reported the concentration of copper as $\leq 20 \mu \mathrm{g} / \mathrm{L}$ in Class I, 50 $\mu \mathrm{g} / \mathrm{L}$ in Class II, $200 \mu \mathrm{g} / \mathrm{L}$ in Class III and $>200 \mu \mathrm{g} / \mathrm{L}$ in Class IV waters. Also, RDWQ (2019) reported the concentration of copper as $2000 \mu \mathrm{g} / \mathrm{L}$ in Class A1, $5000 \mu \mathrm{g} / \mathrm{L}$ in Class A2, and $20000 \mu \mathrm{g} / \mathrm{L}$ in Class A3 waters. In terms of the copper values, Kayalıköy reservoir has Class I and A1 water and is suitable for drinking, agricultural irrigation, and aquaculture.

\section{Zinc}

The concentration of zinc is usually below 10 $\mu \mathrm{g} / \mathrm{L}$ in natural surface waters, and $10-40 \mu \mathrm{g} / \mathrm{L}$ in groundwaters (Elinder 1986). RSWQM (2105) reported the concentration of zinc as $\leq 200 \mu \mathrm{g} / \mathrm{L}$ in Class I, $500 \mu \mathrm{g} / \mathrm{L}$ in Class II, $2000 \mu \mathrm{g} / \mathrm{L}$ in Class III and $>2000 \mu \mathrm{g} / \mathrm{L}$ in Class IV waters. RDWQ (2019) reported the concentration of zinc as $3000 \mu \mathrm{g} / \mathrm{L}$ in Class A1, $6000 \mu \mathrm{g} / \mathrm{L}$ in Class A2, and $12000 \mu \mathrm{g} / \mathrm{L}$ in Class A3 waters. In the present study, the maximum and the minimum zinc concentrations were determined as $9.145 \mu \mathrm{g} / \mathrm{L}$ and $0.818 \mu \mathrm{g} / \mathrm{L}$ in October in the autumn season and in June in the summer season, respectively, with an annual average of $3.585 \pm 2.52 \mu \mathrm{g} / \mathrm{L}$. (Table 2 and Figure 2). In terms of the zinc values, Kayalıköy reservoir has Class I and 
A1 water and is suitable for drinking, agricultural irrigation, and aquaculture. The Zinc $(\mathrm{Zn})$ showed positive significant relationship with $\mathrm{Mg}(\mathrm{r}=791), \mathrm{Ca}$ $(\mathrm{r}=800), \mathrm{Sr}(\mathrm{r}=909), \mathrm{Mn}(\mathrm{r}=800), \mathrm{As}(\mathrm{r}=827), \mathrm{Ba}$ $(\mathrm{r}=845) \quad(\mathrm{p}<0.01), \mathrm{EC} \quad(\mathrm{r}=664), \mathrm{Na} \quad(\mathrm{r}=682), \mathrm{Ba}$ $(\mathrm{r}=718)$ and $\mathrm{Pb}(\mathrm{r}=691)(\mathrm{p}<0.05)($ Table 3$)$.

\section{Arsenic}

The maximum and the minimum arsenic concentrations were determined as $0.077 \mu \mathrm{g} / \mathrm{L}$ and as $1.386 \mu \mathrm{g} / \mathrm{L}$ in December in the spring season and in November in the autumn season, respectively, with an annual average of $0.726 \pm 0.42 \mu \mathrm{g} / \mathrm{L}$. (Table 2 and Figure 2). In drinking-water supplies, arsenic poses a problem because it is toxic at low levels and is a known carcinogen. The concentration of arsenic in natural waters generally ranges between $1-2 \mu \mathrm{g} / \mathrm{L}$ (USNRC 1999). The current recommended limit of arsenic in drinking water is $10 \mu \mathrm{g} / \mathrm{L}$ (WHO 2017). RSWQM (2015) reported the concentration of arsenic as $\leq 20 \mu \mathrm{g} / \mathrm{L}$ in Class I, $50 \mu \mathrm{g} / \mathrm{L}$ in Class II, $100 \mu \mathrm{g} / \mathrm{L}$ in Class III and $>100 \mu \mathrm{g} / \mathrm{L}$ in Class IV waters. Also, RDWQ (2019) reported the concentration of arsenic as $10 \mu \mathrm{g} / \mathrm{L}$ in Class A1, 40 $\mu \mathrm{g} / \mathrm{L}$ in Class $\mathrm{A} 2$, and $50 \mu \mathrm{g} / \mathrm{L}$ in Class A3 waters. According to these results, Kayalıköy reservoir has Class I and A1 water and is suitable for drinking, agricultural irrigation, and aquaculture. The Arsenic (As) showed positive significant relationship with $\mathrm{Mg}(\mathrm{r}=745), \mathrm{Ca}(\mathrm{r}=773), \mathrm{B}(\mathrm{r}=791), \mathrm{Sr}(\mathrm{r}=836), \mathrm{Mn}$ $(\mathrm{r}=764), \mathrm{Zn}(\mathrm{r}=827) \mathrm{Cd}(\mathrm{r}=881), \mathrm{Ba}(\mathrm{r}=855), \mathrm{Pb}$ $(\mathrm{r}=809) \quad(\mathrm{p}<0.01), \mathrm{Na} \quad(\mathrm{r}=700)$ and $\mathrm{Co}(\mathrm{r}=691)$ $(\mathrm{p}<0.05)$ (Table 3).

\section{Selenium}

The concentration of selenium fluctuated during the study from 19.148 to $0.270 \mu \mathrm{g} / \mathrm{L}$ (average $7.046 \pm 5.56 \mu \mathrm{g} / \mathrm{L}$ ). The maximum value of selenium was recorded in November in the autumn season and the minimum in February in the winter season (Table 2 and Figure 2). The levels of selenium in groundwater and surface water range from $0.06 \mu \mathrm{g} / \mathrm{L}$ to about $400 \mu \mathrm{g} / \mathrm{L}$. The current recommended limit of selenium in drinking water is $0.04 \mathrm{mg} / \mathrm{L}(40 \mu \mathrm{g} / \mathrm{L})$ (WHO 2017). For ponds and dam lakes, selenium concentration is $\leq 10 \mu \mathrm{g} / \mathrm{L}$ in Class $\mathrm{I}, \leq 10 \mu \mathrm{g} / \mathrm{L}$ in Class II, $20 \mu \mathrm{g} / \mathrm{L}$ in Class III and $>20 \mu \mathrm{g} / \mathrm{L}$ in Class IV waters (RSWQM 2015). RDWQ (2019) reported the concentration of selenium as $10 \mu \mathrm{g} / \mathrm{L}$ in Class $\mathrm{A} 1$, $20 \mu \mathrm{g} / \mathrm{L}$ in Class $\mathrm{A} 2$, and $100 \mu \mathrm{g} / \mathrm{L}$ in Class A3 waters. According to these results, Kayal1köy reservoir has been Class I and A1 water.

\section{Molybdenum}

The concentration of molybdenum was determined by the maximum $33.543 \mu \mathrm{g} / \mathrm{L}$ and the minimum $0.602 \mu \mathrm{g} / \mathrm{L}$. The average molybdenum concentration in the reservoir was measured as
$14.071 \pm 10.85 \mu \mathrm{g} / \mathrm{L}$. The maximum values of molybdenum were recorded in July in the winter season and the minimum in April in spring season (Table 2 and Figure 2). Molybdenum plays an important biological role as a micronutrient for plants and animals. At high levels, it can be toxic to animals. The current recommended limit of molybdenum in drinking water is $0.02 \mathrm{mg} / \mathrm{L}(20 \mu \mathrm{g} / \mathrm{L})$ (WHO 2017). According to these results, Kayalıköy reservoir has clean water characteristics.

\section{Cadmium}

The maximum and the minimum cadmium concentrations were determined as $0.260 \mu \mathrm{g} / \mathrm{L}$ and as $0.008 \mu \mathrm{g} / \mathrm{L}$ in September in the autumn season and in April in spring season, respectively, with an annual average of $0.097 \pm 0.07 \mu \mathrm{g} / \mathrm{L}$. (Table 2 and Figure 2). Cadmium occurs naturally in zinc, in lead and copper ores, in coal and other fossil fuels, and is released during volcanic action. The concentration of cadmium in drinking water is $0.003 \mathrm{mg} / \mathrm{L}(3 \mu \mathrm{g} / \mathrm{L})$ (WHO 2017). RSWQM (2015) reported the concentration of cadmium as $\leq 2 \mu \mathrm{g} / \mathrm{L}$ in Class I, 5 $\mu \mathrm{g} / \mathrm{L}$ in Class II, $7 \mu \mathrm{g} / \mathrm{L}$ in Class III and $>7 \mu \mathrm{g} / \mathrm{L}$ in Class IV waters. According to these results, Kayalıköy reservoir has the characteristics of clean water and Class I water. The Cadmium (Ca) showed positive significant relationship with $\mathrm{Co}(\mathrm{r}=882)$, As $(\mathrm{r}=818), \mathrm{Pb}(\mathrm{r}=764)(\mathrm{p}<0.01), \mathrm{Be}(\mathrm{r}=670), \mathrm{B}(\mathrm{r}=709)$, $\mathrm{V}(\mathrm{r}=645), \mathrm{Sb}(\mathrm{r}=618), \mathrm{Ba}(\mathrm{r}=664)$ and $\mathrm{Tl}(\mathrm{r}=664)$ $(\mathrm{p}<0.05)$ (Table 3$)$.

\section{Antimony}

Antimony is a metal that is present naturally in small quantities in water, rocks, and soils. In the present study, the maximum and the minimum antimony concentrations were determined as 199.900 $\mu \mathrm{g} / \mathrm{L}$ and $0.053 \mu \mathrm{g} / \mathrm{L}$ in December in the winter season and in April in the spring season, respectively, with an average value of $22.191 \pm 59.28 \mu \mathrm{g} / \mathrm{L}$ (Table 2 and Figure 2). Concentrations of antimony in groundwater and surface water normally range from 0.1 to $0.2 \mu \mathrm{g} / \mathrm{L}$ (Bowen 1979) and were $0.02 \mathrm{mg} / \mathrm{L}$ $(20 \mu \mathrm{g} / \mathrm{L})$ in drinking water (WHO 2017). RDWQ (2019) reported the concentration of antimony as is 5 $\mu \mathrm{g} / \mathrm{L}$ in Class A1, $15 \mu \mathrm{g} / \mathrm{L}$ in Class $\mathrm{A} 2$, and $50 \mu \mathrm{g} / \mathrm{L}$ in Class A3 waters. According to these results, Kayalıköy reservoir has Class A1 water and is suitable for drinking, agricultural irrigation, and aquaculture.

\section{Barium}

Barium is not considered to be an essential element for human nutrition. Barium is a divalent cation and alkaline earth metal that can be found in naturally occurring mineral deposits. In the present study, the maximum and the minimum barium concentrations were determined as $5.486 \mu \mathrm{g} / \mathrm{L}$ and as 
42.963 in April in the winter season and in October in the autumn season, respectively, with an annual average of $23.482 \pm 11.91 \mu \mathrm{g} / \mathrm{L}$ (Table 2 and Figure 2). Concentrations in drinking water of barium are generally below $100 \mu \mathrm{g} / \mathrm{L}$, although the acceptable value is $1.3 \mathrm{mg} / \mathrm{L}(1300 \mu \mathrm{g} / \mathrm{L})$ in drinking water (WHO 2019). RSWQM (2015) reported the concentration of barium as $\leq 1000 \mu \mathrm{g} / \mathrm{L}$ in Class I, $2000 \mu \mathrm{g} / \mathrm{L}$ in Class II and III, and $>2000 \mu \mathrm{g} / \mathrm{L}$ in Class IV waters. Also, RDWQ (2019) reported the concentration of barium is $2000 \mu \mathrm{g} / \mathrm{L}$ in Class A1 and $20000 \mu \mathrm{g} / \mathrm{L}$ in Class A3 waters. According to these results, Kayalıköy reservoir has Class I and A1 water and is suitable for drinking, agricultural irrigation, and aquaculture. The Barium (Ba) showed positive significant relationship with $\mathrm{Ca}(\mathrm{r}=855), \mathrm{Sr}(\mathrm{r}=900)$, Mn ( $\mathrm{r}=882), \mathrm{Zn}(\mathrm{r}=845)$, As ( $\mathrm{r}=655), \mathrm{Pb}(\mathrm{r}=909)$ $(\mathrm{p}<0.01), \mathrm{Na}(\mathrm{r}=636), \mathrm{Mg}(\mathrm{r}=700), \mathrm{B}(\mathrm{r}=691), \mathrm{Cu}$ $(\mathrm{r}=718)$ and $\mathrm{Cd}(\mathrm{r}=664)(\mathrm{p}<0.05)$ (Table 3$)$.

\section{Thallium}

Thallium is released into the biosphere from both natural and anthropogenic sources. Thallium is considered toxic for human and animal organisms, microorganisms, and plants. In the present study, the thallium concentrations were detected the maximum $0.260 \mu \mathrm{g} / \mathrm{L}$ and the minimum $0.012 \mu \mathrm{g} / \mathrm{L}$. The average values of thallium were determined $0.119 \pm 0.08 \mu \mathrm{g} / \mathrm{L}$ in the reservoir. The maximum concentration of thallium was recorded in September in the autumn season and the minimum in April in winter season (Table 2 and Figure 2). The concentration of antimony in drinking water is $2 \mu \mathrm{g} / \mathrm{L}$ (USEPA 2008). According to these results, Kayalıköy reservoir has the characteristics of clean water.

\section{Lead}

Lead is a naturally occurring metal found in rock, soil, water, and sediment. In the present study, maximum and the minimum lead concentrations were determined as $2.790 \mu \mathrm{g} / \mathrm{L}$ and $0.122 \mu \mathrm{g} / \mathrm{L}$ in September in the autumn season and in April in the spring season with an average value of $0.873 \pm 0.73$ $\mu \mathrm{g} / \mathrm{L}$ (Table 2 and Figure 2). The concentration of lead in drinking water is $2 \mathrm{mg} / \mathrm{L}(200 \mu \mathrm{g} / \mathrm{L})($ WHO 2017). RSWQM (2015) reported the concentration of lead as $\leq 10 \mu \mathrm{g} / \mathrm{L}$ in Class I, $20 \mu \mathrm{g} / \mathrm{L}$ in Class II, 50 $\mu \mathrm{g} / \mathrm{L}$ in Class III and III, $>50 \mu \mathrm{g} / \mathrm{L}$ in Class IV waters. RDWQ (2019) reported the concentration of lead as $10 \mu \mathrm{g} / \mathrm{L}$ in Class A1, $50 \mu \mathrm{g} / \mathrm{L}$ in Class A2, and 100 $\mu \mathrm{g} / \mathrm{L}$ in Class A3 waters. According to these results, the reservoir shows Class I and A1 water characteristics in terms of lead and is suitable for drinking, agricultural irrigation, and aquaculture.

As a result, water samples taken from three stations determined in Kayalıköy reservoir for one year were examined in terms of some physicochemical parameters and heavy metal concentrations. The results were compared with RSWQM (National Standart for Turkish inland water Regulation on Modification of Surface Water Quality Management) and RDWQ (Regulation on the Quality and Treatment of Water Provided for Drinking Water). The water quality properties were assessed, the suitability levels in terms of aquatic life, agricultural irrigation, and aquaculture and drinking water were determined.

The Nitrite nitrogen was determined above the limit values in May, June, and July in the summer season. Also, phosphate in May, chlorine in October, aluminum in February, chromium in June, and selenium in November were determined above the limit values. However, the increase in these values in short periods can be attributed to excessive water withdrawal in the reservoir. The trophic status of Kayalıköy reservoir was classified as eutrophic according to Secchi disc depth and as mesotrophic according to Chlorophyll-a. It can be classified as oligotrophic character according to other parameters. As can be seen in the average values of the analysis results, the water quality in Kayalıköy reservoir is generally considered to be Class I and A1 water according to RSWQM and RDWQ. In short, Kayalıköy reservoir has water suitable for drinking, agricultural irrigation, and aquaculture and was classified as having oligomesotrophic character.

No such a long term and more detailed study have been carried out in the dam lakes in the Thrace region where the Kayal1köy dam is located. However, along with planktonic organisms in Süloğlu and Kadıköy dam lakes, some physicochemical properties of water have also been studied (Güher and Çolak 2015; Tokatl1 et al. 2017; Güher 2019). As a result of these studies, it was reported that the water of Süloğlu reservoir is in Class I and II and of oligo-mesotrofic character in most parameters, and that of Kadıköy reservoir is in Class II and of meso-eutrophic character. Also, some physicochemical parameters of water in Kayalıköy reservoir were studied only for two months (November and April) (Kanarya 2013). The results obtained in these studies are in parallel with our results. However, constant monitoring activities should be performed in reservoirs in general.

The fact that no factors are affecting (industry, residential areas, agricultural areas etc.) the lake around Kayalıköy dam lake is a big advantage. Changes in the water level in the reservoir brought on by changes in the evaporation and precipitation amounts depending on seasonal conditions as well as the purpose and amount of water usage are one of the most important factors in the change of 
physicochemical parameters. Therefore, excessive water outflow in the lake for drinking water and agricultural irrigation are affecting the physicochemical properties of lake water. To protect the water quality of the lake water should be controlled by the absolute output of the lake. To maintain the water quality of the lake, the water outlets in the lake must be controlled.

To protect water quality and to ensure the continuation of aquatic life in this reservoir, it is necessary to make regular observations and to monitor the environmental parameters affecting water quality and aquatic life. Also, the results obtained from this study can be considered as a reference which can be used to evaluate possible future changes in the reservoir and will provide a good reference for setting standards for water quality.

\section{Acknowledgements}

This research has been supported by TÜBAP2018/66 project.

\section{References}

Arrignon J. 1976. Aménagement ecologique et piscicole des eaux douces. Bordas, Paris: Grand public. 320 p.

ATSDR 2002. Toxicological profile for copper (draft for public comment). Atlanta, GA, US Department of Health and Human Services, Public Health Service, Agency for Toxic Substances and Disease Registry (Subcontract No. ATSDR-205-1999-00024). [Date of access: 11.08.2019]. Accessed from https://babel.hathitrust.org/cgi/pt?id=mdp.390150526 $71453 \&$ view $=1$ up\&seq $=3$

Barceloux DG. 1999. Manganese. Clin Toxicology. 37(2):293-307. doi: $10.1081 /$ clt-100102427

Barlas M, İkiel C, Özdemir N. 1995. Gökova Körfezi’ne akan tatlı su kaynaklarının fiziksel ve kimyasal açıdan incelenmesi. Doğu Anadolu Bölgesi I. ve II. Su Ürünleri Sempozyumu, 14-16 Haziran: Erzurum, Türkiye, 704-712. [in Turkish]

Berzins B, Pejler B. 1987. Rotifer occurrence in relation to $\mathrm{pH}$. Hydrobiologia, 147:107-116. doi: 10.1007/BF00025733

Bowen HJM. 1979. Environmental chemistry of the elements. London: Academic Press, 333 p.

Bremond R, Vuichard R. 1973. Parameters de la qualite des eaux. Ministere de la Protection de la Nature et de Environnement Documentation, Française, Paris 179 p.

Bulut C, Kubilay A. 2018. Eğirdir Gölü su kalitesinin trofik durum indeksleriyle belirlenmesi. Acta Aquatica Turcica. 14(4):324-338. doi: 10.22392/egirdir.415073. [in Turkish]

Butterwick L, De Oude N, Raymond K. 1989. Safety assessment of boron in aquatic and terrestrial environments. Ecotox Environ Safe. 17:339-371. doi: 10.1016/0147-6513(89)90055-9
Caspers H. 1984. OECD: Eutrophication of waters. Monitoring, assessment and control. 154 p. Paris: Organisation for Economic Co-Operation and Development 1982. (Publié en français sous le titre Eutrophication des Eaux. Méthodes de Surveillance, d'Evaluation et de Lutt. Int Rev der gesamten Hydrobiol und Hydrogr. 69:200 doi:10.1002/iroh.19840690206

Das Kangabam R, Govindaraju M. 2017. Anthropogenic activity-induced water quality degradation in the Loktak Lake, a Ramsar site in the Indo-Burma biodiversity hotspot. Environ Technol. 1-10. doi: $10.1080 / 09593330.2017 .1378267$

Dauba F. 1981. Etude comperative de la fauna des poissons dans les ecosystemes de deux reservoirs, Luzech (Lut) et Chastang (Dordogone). These de troisieme cycle L'Institut National Polytechnique de Toulouse, $179 \mathrm{p}$.

Dixon W, Chiswell B. 1996. Review of aquatic monitoring program design. Water Res. 30:1935-1948. doi.org/10.1016/0043-1354(96)00087-5

Egemen Ö, Sunlu U. 1996. Su Kalitesi. İzmir: Ege Üniversitesi Basımevi 153 p. [in Turkish]

Elinder CG. 1986. Zinc. In: Friberg L, Nordberg GF, Vouk VB, editors. Handbook on the toxicology of metals, 2nd ed. Amsterdam: Elsevier Science Publishers. 664$679 \mathrm{p}$.

EPA 2001. (Environmental Protection Agency) Method 200.7. 2001. Determination of metals and trace elements in water and wastes by inductively coupled plasma-atomic emission spectrometry.

FPTC 2018. Federal-Provincial-Territorial Committee. Strontium in drinking water guideline technical document for public consultation prepared by the federal-provincial-territorial committee on drinking water consultation period ends July 20. [Date of access: 11.08.2019]. Accessed from https://www.canada.ca/en/healthcanada/programs/co nsultation-strontium-drinking-water/document.html

Gikas GD, Tsihrintzis VA, Akratos CS, Haralambidis G. 2009. Water quality trends in Polyphytos reservoir, Aliakmon River, Greece. Environ Monit Assess. 149:163-181. doi: 10.1007/s10661-008-0191-Z

Güher H, Çolak Ş. 2015. Süloğlu Baraj Gölü’nün (Edirne) zooplankton (Rotifera, Cladocera, Copepoda) faunas1 ve mevsimsel değişimi. Trakya University Journal of Natural Sciences. 16(1)17-24. [in Turkish]

Güher H. 2019. Seasonal variation of planktonic microcrustacea (Copepoda, Cladocera) diversity in Kadiköy Reservoir (Edirne/Turkey). Acta Aquatica Turcica. 15(2):188-196. doi: 10.22392 /actaquatr.484963

Kanarya G. 2013. Kirklareli yöresindeki sulama suyu kaynaklarında bulunan bazı makro ve mikro elementlerin tarımsal açıdan değerlendirilmesi üzerine bir araştırma. [Yüksek Lisans Tezi]. Namık Kemal Üniversitesi, 105 p. [in Turkish]

Köse E, Tokatlı C, Çiçek A. 2014. Monitoring stream water quality: A statistical evaluation. Pol J Environ Stud. 23(5):1637-1647. 
Krebs CJ. 1999. Ecological Methodology. California: Addison Wesley Longman Inc. 620 p.

Kükrer S, Mutlu E. 2019. Assessment of surface water quality using water quality index and multivariate statistical analyses in Saraydüzü dam lake, Turkey. Environ Monit Assess. 191:71. doi: 10.1007/s10661-019-7197-6

Loukas A. 2010. Surface water quantity and quality assessment in Pinios River, Thessaly, Greece. Desalination. 250(1):266-273.

doi: 10.1016/j.desal.2009.09.043

Minareci O, Çakır M. 2018. Determination of detergent, phosphate, boron and heavy metal pollution in Adıgüzel dam lake (Denizli/Turkey). Iğdır Univ. J. Inst. Sci. \& Tech. 8(1):61-67. doi: $10.21597 /$ jist.407817

Mutlu E, Demir T, Yanik T, Sutan NA. 2016. Determination of environmentally relevant water quality parameters in Serefiye dam-Turkey. Fresenius Environmental Bulletin. 25(12):5812-5818.

Nisbet M, Verneaux J. 1970. Composants chimiques des eaux courantes: discussion et propositions des classes en tant que base d'interprétation des analyses chimiques. Ann Limnol-Int J Lim. 6(2):161-190. doi: 10.1051/limn/1970015

NWQMC 2016. National Water Quality Monitoring Council. Water Quality Portal, October 2018. [Date of access: 11.08.2019]. Accessed from https://www.waterqualitydata.us

Öztürk YB, Akköz C. 2014. Investigation of water quality of Apa dam lake (Çumra-Konya) and according to the evolution of PCA. Biological Diversity and Conservation. 7(2):136-147.

RDWQ 2019. İçme suyu temin edilen suların kalitesi ve arıtılması hakkında yönetmelik. Tarım ve Orman Bakanlığı: 6 Temmuz 2019, Sayı: 30823 Resmî Gazete. [Erişim tarihi: 10.11.2019]. Erişim adresi: https://www.resmigazete.gov.tr/eskiler/2015/04/2015 0415-18.htm [in Turkish]

RSWQM 2015. Yüzeysel su kalitesi yönetimi yönetmeliğinde değişiklik yapılmasına dair yönetmelik. Orman ve $\mathrm{Su}$ İşleri Bakanlığg: 15 Nisan 2015, Sayı: 29327 Resmî Gazete. [Erişim tarihi: 10.11.2019]. Erişim adresi: https://www.resmigazete.gov.tr/eskiler/2015/04/2015 0415-18.htm [in Turkish]

Ryding SO, Rast W. 1989. The control of eutrophication of lakes and reservoirs. UNESCO, Man and the Biosphere Series Volume I. London: Parthenon Press $314 \mathrm{p}$.

Samian M, Naderi MK, Saadi H, Movahedi R. 2015. Identifying factors affecting optimal management of agricultural water. Journal of the Saudi Society of Agricultural Sciences. 14(1):11-18. doi: 10.1016/j.jssas.2014.01.001

Shanker AK, Cervantes C, Loza-Tavera H, Avudainayagam S. 2005. Chromium toxicity in plants. Environ Int. 31:739-753. doi: $10.1016 /$ j.envint.2005.02.003

Slooff W. 1989. Integrated criteria document chromium. Bilthoven, Netherlands: National Institute of Public
Health and Environmental Protection. Report no. 758701002.

Strobl RO, Robillard PD. 2008. Network design for water quality monitoring of surface freshwaters: a review. $\mathrm{J}$ Environ Manage. 87:639-648. doi: 10.1016/j.jenvman.2007.03.001

Taş B, Candan AY, Can Ö, Topkara S. 2010. Ulugöl (Ordu)'ün bazı fizikokimyasal özellikleri. Journal of FisheriesSciences.com. 4(3):254-263. [in Turkish]

Taş B. 2011. Gaga Gölü (Ordu, Turkey) su kalitesinin incelenmesi. Black Sea Technical University's Journal of Science. 1(3):43-61. [in Turkish]

Tepe R, Kutlu B. 2019. Examination water quality of Karkamış dam lake. Turkish Journal of AgricultureFood Science and Technology. 7(3):458-466. doi: 10.24925/turjaf.v7i3.458-466.2409

Tepe Y. 2009. Reyhanlı Yenişehir Gölü (Hatay) su kalitesinin belirlenmesi. Ekoloji. 18(70):38-46. doi: 10.5053/ekoloji.2009.706. [in Turkish]

Thomann RV, Mueller JA. 1987. Principle of surface water quality modelling and control. New York: Harper and Row Publishers 644 p.

Thornton KW, Kimmel BL, Payne FE. 1990. Reservoir limnology: Ecological Perspectives. New York: John Wiley \& Sons $246 \mathrm{p}$.

Tokatlı C, Baştatlı Y, Elipek B. 2017. Water quality assessment of dam lakes located in Edirne province (Turkey). Sigma Journal of Engineering and Natural Sciences. 35(4):743-750.

Uncumusaoğlu AA, Mutlu E. 2017. Determination of water quality and usability level of Eğlence Pond (Boyabat, Sinop). Alınteri Journal of Agricultural Sciences. 32(2):25-37. doi: 10.28955/alinterizbd.332812

Ünlü A, Çoban F, Tunç MS. 2008. Hazar Gölü su kalitesinin fiziksel ve inorganik kimyasal parametreler açısından incelenmesi. Gazi Üniversitesi Mühendislik-Mimarlık Fakültesi Dergisi. 23(1):119127. [in Turkish]

USEPA 2002. United States Environmental Protection Agency. Occurrence summary and use support document for the six-year review of national primary drinking water regulations. Washington, DC: United States Environmental Agency, Office of Water (EPA-815-D-02-006). [Date of access: 11.08.2019]. Accessed from https://nepis.epa.gov/Exe/ZyPDF.cgi/20001X16.PDF ?Dockey $=20001 \mathrm{X} 16 . \mathrm{PDF}$

USEPA 2008. United States Environmental Protection Agency. Drinking water contaminant candidate List 3 draft; notice. Federal Register. 73(35)9627-9654 p. [Date of access: 11.08.2019]. Accessed from https://www.federalregister.gov/d/E8-3114

USNRC 1999. United States National Research Council. Arsenic in drinking water. Washington, DC, The National Academies Press. 331 p. doi: 10.17226/6444

White GC. 1978. Current chlorination and dechlorination practices in the treatment of potable water, wastewater and cooling water. In: Jolley RL, editor. Water chlorination: environmental impact and health effects. 
Vol. 1. Ann Arbor, MI, Ann Arbor Science: 1-18.

WHO 1998. Guidelines for drinking-water quality: second edition, Addendum to Volume 2 Health criteria and other supporting information. Geneva: World Health Organization, WHO/EOS/98.1.

WHO 2008. Guidelines for drinking-water quality; third edition incorporating the first and second addenda volume 1 Recommendations. Geneva: World Health
Organization. ISBN 9789241547611.

WHO 2017. Guidelines for drinking-water quality: fourth edition, incorporating the first addendum. Geneva: World Health Organization. Licence: CC BY-NC-SA 3.0 IGO.

Yücel A. 1990. Kırşehir Seyfe Gölü bentik alg florası. [Yüksek Lisans Tezi]. Ankara Üniversitesi, 137 p. [in Turkish] 